Article

\title{
Extracellular Vesicles Derived from Mesenchymal Stromal Cells Delivered during Hypothermic Oxygenated Machine Perfusion Repair Ischemic/Reperfusion Damage of Kidneys from Extended Criteria Donors
}

Teresa Rampino ${ }^{1}$, Marilena Gregorini ${ }^{1,2, * \mathbb{D}}$, Giuliana Germinario ${ }^{3,4} \mathbb{D}$, Eleonora Francesca Pattonieri ${ }^{1}$, Fulvia Erasmi ${ }^{1}$, Maria Antonietta Grignano ${ }^{1} \mathbb{D}$, Stefano Bruno ${ }^{5,6}$, Esra Alomari ${ }^{5}$, Stefano Bettati ${ }^{6,7} \mathbb{D}$, Annalia Asti ${ }^{1}$ (D), Marina Ramus ${ }^{1}$, Mara De Amici ${ }^{8}$, Giorgia Testa ${ }^{9}$, Stefania Bruno ${ }^{10} \mathbb{D}$, Gabriele Ceccarelli $^{11}{ }^{(D)}$, Nicoletta Serpieri ${ }^{1}$, Carmelo Libetta ${ }^{1,2}$, Vincenzo Sepe ${ }^{1}$, Flavia Blasevich ${ }^{12}$, Federica Odaldi ${ }^{3}$, Lorenzo Maroni ${ }^{3}$, Francesco Vasuri ${ }^{13}$, Gaetano La Manna ${ }^{14}$ and Matteo Ravaioli ${ }^{3,4}{ }^{\text {D }}$

check for

updates

Citation: Rampino, T.; Gregorini, M.; Germinario, G.; Pattonieri, E.F.; Erasmi, F.; Grignano, M.A.; Bruno, S.; Alomari, E.; Bettati, S.; Asti, A.; et al. Extracellular Vesicles Derived from Mesenchymal Stromal Cells Delivered during Hypothermic Oxygenated Machine Perfusion Repair Ischemic/Reperfusion Damage of Kidneys from Extended Criteria Donors. Biology 2022, 11, 350. https://doi.org/10.3390/ biology 11030350

Academic Editors: Arsalan Haqqani and Amanpreet Badhwar

Received: 20 January 2022 Accepted: 18 February 2022 Published: 22 February 2022

Publisher's Note: MDPI stays neutral with regard to jurisdictional claims in published maps and institutional affiliations.

Copyright: (C) 2022 by the authors. Licensee MDPI, Basel, Switzerland. This article is an open access article distributed under the terms and conditions of the Creative Commons Attribution (CC BY) license (https:// creativecommons.org/licenses/by/ $4.0 /)$.
1 Department of Nephrology, Dialysis and Transplantation, Fondazione IRCCS Policlinico San Matteo, University of Pavia, 27100 Pavia, Italy; t.rampino@smatteo.pv.it (T.R.); ef.pattonieri@smatteo.pv.it (E.F.P.); fulvia.erasmi89@gmail.com (F.E.); wta87@hotmail.it (M.A.G.); annalia.asti@unipv.it (A.A.); marina.ramus01@universitadipavia.it (M.R.); n.serpieri@smatteo.pv.it (N.S.); carmelo.libetta@unipv.it (C.L.); v.sepe@smatteo.pv.it (V.S.)

2 Department of Internal Medicine and Therapeutics, University of Pavia, 27100 Pavia, Italy

3 Department of General Surgery and Transplantation, IRCCS, Azienda Ospedaliero-Universitaria di Bologna, 40138 Bologna, Italy; giuliana.germinario2@unibo.it (G.G.); fede.odaldi@gmail.com (F.O.); lorenzo.maroni@aosp.bo.it (L.M.); matteo.ravaioli6@unibo.it (M.R.)

4 Dipartimento di Scienze Mediche e Chirurgiche (DIMEC), University of Bologna, 40126 Bologna, Italy

5 Department of Food and Drug, University of Parma, 43124 Parma, Italy; stefano.bruno@unipr.it (S.B.); esraa.alomari@iu.edu.jo (E.A.)

6 Biopharmatec TEC, University of Parma, Tecnopolo Padiglione 33, 43124 Parma, Italy; stefano.bettati@unipr.it

7 Department of Medicine and Surgery, University of Parma, 43125 Parma, Italy

8 Laboratory of Immuno-Allergology of Clinical Chemistry and Pediatric Clinic, Fondazione IRCCS Policlinico S. Matteo, 27100 Pavia, Italy; M.DeAmici@smatteo.pv.it

9 Department of Pediatrics, Fondazione IRCCS Policlinico San Matteo, University of Pavia, 27100 Pavia, Italy; g.testa@smatteo.pv.it

10 Department of Medical Sciences and Molecular Biotechnology Center, University of Torino, 10126 Torino, Italy; stefania.bruno@unito.it

11 Human Anatomy Unit, Department of Public Health, Experimental and Forensic Medicine, University of Pavia, 27100 Pavia, Italy; gabriele.ceccarelli@unipv.it

12 Department of Neuroimmunology and Neuromuscular Diseases, Fondazione IRCCS Neurological Institute Carlo Besta, 20133 Milan, Italy; flavia.blasevich@istituto-besta.it

13 "F. Addarii" Institute of Oncology and Transplantation Pathology, S. Orsola-Malpighi University Hospital, 40138 Bologna, Italy; francesco.vasuri@aosp.bo.it

14 Department of Nephrology, S.Orsola-Malpighi Hospital, University of Bologna, 40138 Bologna, Italy; gaetano.lamanna@unibo.it

* Correspondence: marilena.gregorini@unipv.it; Tel.: +39-0382-503896

Simple Summary: In this study, we explore for the first time an innovative tool for organ preservation aimed to preventing ischemia reperfusion injury (IRI) in marginal kidneys from expanded criteria donors (ECD) unsuitable for transplantation. Ex vivo hypothermic oxygenated perfusion (HOPE) with and without MSC-derived EV and normothermic reperfusion (NR) with artificial blood composed of bovine hemoglobin were applied on kidneys to evaluate global renal ischemic damage score, renal ultrastructure, mitochondrial distress, apoptosis, cell proliferation index, and the mediators of energy metabolism. Our study demonstrates that kidney conditioning with HOPE+EV arrests the ischemic damage, prevents reoxygenation-dependent injury, and preserves tissue integrity. EV delivery during HOPE can be considered a new organ preservation strategy to increase the donor pool and improving transplant outcome. The originality of our study lies an EV and HOPE combined novel setting use in kidneys from ECD, but also in any condition for graft dysfunction such as ischemia/reperfusion. 


\begin{abstract}
The poor availability of kidney for transplantation has led to a search for new strategies to increase the donor pool. The main option is the use of organs from extended criteria donors. We evaluated the effects of hypothermic oxygenated perfusion (HOPE) with and without extracellular vesicles (EV) derived from mesenchymal stromal cells on ischemic/reperfusion injury of marginal kidneys unsuitable for transplantation. For normothermic reperfusion (NR), we used artificial blood as a substitute for red blood cells. We evaluated the global renal ischemic dam-age score (GRS), analyzed the renal ultrastructure (RU), cytochrome c oxidase (COX) IV-1 (a mitochondrial distress marker), and caspase-3 renal expression, the tubular cell proliferation index, hepatocyte growth factor (HGF) and vascular endothelial growth factor (VEGF) tissue levels, and effluent lactate and glucose levels. HOPE+EV kidneys had lower GRS and better RU, higher COX IV-1 expression and HGF and VEGF levels and lower caspase-3 expression than HOPE kidneys. During NR, HOPE+EV renal effluent had lower lactate release and higher glucose levels than HOPE renal effluent, suggesting that the gluconeogenesis system in HOPE+EV group was pre-served. In conclusion, EV delivery during HOPE can be considered a new organ preservation strategy for increasing the donor pool and improving transplant outcome.
\end{abstract}

Keywords: ischemia/reperfusion injury; kidney transplantation; machine perfusion; expanded criteria donors; mesenchymal stromal cells; extracellular vesicles; COXIV-1; caspase 3; HGF; VEGF

\title{
1. Introduction
}

Kidney transplantation represents the gold-standard treatment for patients with endstage renal disease. Unfortunately, the huge gap between the number of transplant candidates and organ availability has had a significant impact on patient morbidity and mortality. Although new therapies such as mesenchymal stromal cells (MSC) and drug monitoring have improved graft outcomes [1-3], new strategies are needed for increasing the donor pool. At present, the main option is to use marginal kidney allografts from older donors with comorbidities such as hypertension, mild renal impairment, and death from cerebrovascular events, defined as extended criteria donors (ECD) $[4,5]$.

However, ECD organs are more exposed to ischemic/reperfusion injury (IRI) compared to those from standard donors. Consequently, their use presents an increased risk of primary non-function, delayed graft function, and decreased graft survival [6-10].

IRI pathophysiology consists of two phases: the initial ischemic phase involving interrupted blood flow to the organs, and the reperfusion phase, in which the blood flow is restored. During ischemia, there is a switch from aerobic to anaerobic metabolism, which leads to intracellular changes: ATP levels decline, intracellular protons and calcium increase; there is cytoskeletal, mitochondrial, and endoplasmic reticulum dysfunction and cellular swelling occurs. Although restoring the blood flow is essential for reversing the damage caused by ischemia, it may also result in reoxygenation-dependent injury due to reactive oxygen species (ROS) increase, mitochondrial and cellular membrane peroxidation, the recruitment of immune and inflammatory cells, and activation of the programmed cell death pathways. Combined with low energy storage, all of these events can lead to irreversible injury of marginal kidneys, unless rapidly treated [11-16].

To increase the number of successful transplants, the use of machine perfusion (MP) is currently proposed for assessing organ viability prior to transplantation, but also to attenuate organ damage, limiting the discard rate [17-21]. In fact, it has been proven in several animal models that MP has a protective role against apoptosis by reducing caspase activation and for improving circulation [22]. The main effects of MP are the removal of waste products and inflammatory mediators and the supplementation of metabolic substrates for generating ATP and glutathione, which protect against ROS [23-26].

At present, dynamic MP can be performed in hypothermic (HMP) or normothermic (NMP) conditions with or without oxygen. Both perfusion systems increase the survival of organs harvested from ECD [21,27-31]. 
Recently, we have shown that hypothermic oxygenated machine perfusion (HOPE) for ECD grafts is safe and protects organs from IRI by restoring ATP levels, improving function recovery and kidney and liver transplantation outcomes [32-36].

The addition of hemoglobin-based oxygen carriers (HBOCs) [37] in the perfusion solution under NMP conditions increases tissue oxygenation. Several NMP experiments have shown that HBOCs yield similar, if not better, results in comparison to red blood cells (RBCs) in the liver [38] and kidney [39].

Dynamic MP also presents the possibility of delivering targeted therapies to organs before transplantation. Using a kidney donation after circulatory death (DCD) rat model, we have demonstrated that MSC/MSC-derived extracellular vesicles (EV) delivered during HMP protected kidneys from ischemic injury. In particular, we observed the up regulation of genes encoding enzymes that improve cell energy metabolism and ion membrane transport in MSC EV-treated kidneys [40]. Several other studies have shown the beneficial effects of MSC/MSC-derived EV in IRI models. They accelerate renal recovery after damage, promoting cell proliferation and blocking inflammation and apoptosis. [3,41-46] Based on these data, we hypothesized that the combined use of HOPE and EV, i.e., the delivery of EV during HOPE, may enhance their individual beneficial effects on IRI. In the present study, we explored for the first time an innovative tool for organ preservation aimed at preventing IRI damage in vulnerable marginal kidneys.

We applied ex vivo HOPE to which MSC-derived EV had been added as a preservation technique in discarded organs from ECD after brain death. We also designed a normothermic reperfusion (NR) phase using HBOCs as RBC substitutes to explore whether EV action may also prevent reoxygenation-dependent injury.

\section{Materials and Methods}

\subsection{Study Design}

This single-center, prospective, interventional arm pilot randomized clinical study applied MSC-derived EV therapy combined with MP in discarded human kidneys from ECD. This study was performed at the General Surgery and Transplant Unit of the IRCCS, Azienda Ospedaliero-Universitaria of Bologna in accordance with the Helsinki Declaration. All experimental procedures were approved by the Ethics in Research Committee in June 2016. The study has been registered at ClinicalTrials.gov (ClinicalTrials.gov ID: NCT03837197) (Figure 1).

\subsection{Eligibility}

Kidneys deemed ineligible for transplant were recruited consecutively in the study from June 2019 to June 2020. The inclusion criteria were: marginal kidney pairs considered non-eligible for transplantation, with histological Remuzzi score $\geq 5$ [47]. The exclusion criteria were: kidneys eligible for single or double kidney transplantation, kidneys not technically compatible with reperfusion due to anatomical vascular and/or excretory anomalies, kidneys from donors with serological positivity for anti- hepatitis $\mathrm{C}$ virus (HCV) antibodies and/or seropositive for Human immunodeficiency virus (HIV), and all cases of kidneys with non-calculable infectious donation risk.

\subsection{Organ Retrieval}

Organs were procured using the technique developed by Starzl [48]. Following aortic clamping, the abdominal organs were flushed in situ through the aorta with cold Celsior or Belzer solution (Bridge to Life, Columbia, SC, USA), retrieved, dipped in a bag filled with preservation fluid, and stored on ice. Pre-transplant biopsies were performed ac-cording to our retrieval protocol. The retrieved organs were stored on ice during the trans-fer from the donor to the transplant hospital, during the biopsy analysis, until cross-matched results were returned, and until the final decision of non-eligible kidneys. 


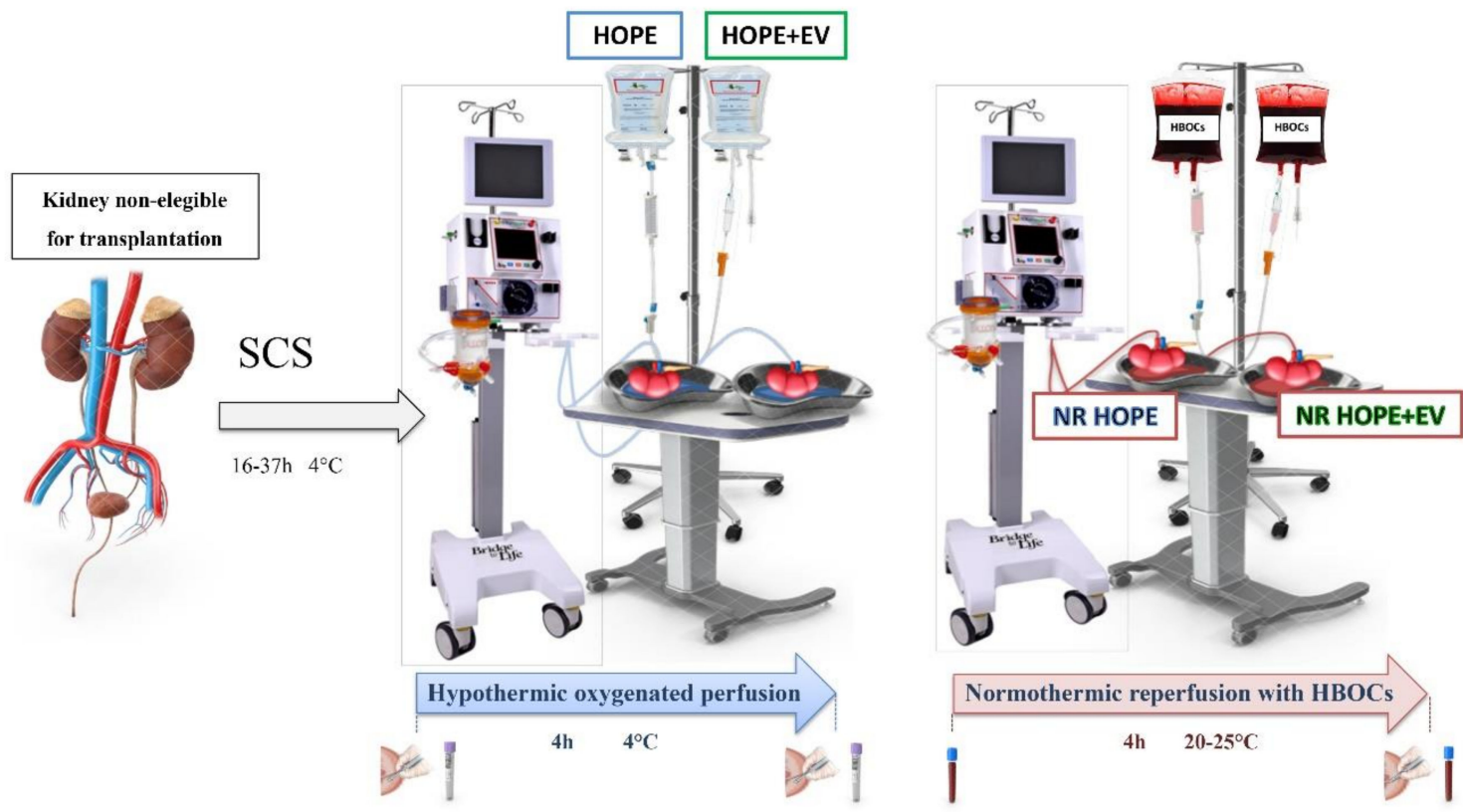

Figure 1. Trial design. Samples of effluent were collected at the beginning and end of HOPE and normothermic reperfusion. Biopsies were performed at the end of hypothermic and normothermic preservations. SCS, static cold storage; HOPE, hypothermic oxygenated machine perfusion; $\mathrm{HOPE}+\mathrm{EV}$, hypothermic oxygenated machine perfusion with extracellular vesicles derived from mesenchymal stromal cells; HBOCs, hemoglobin-based oxygen carriers; NR HOPE, normothermic reperfusion of HOPE-perfused kidneys; NR HOPE+EV, normothermic reperfusion of HOPE+EVperfused kidneys.

\subsection{Randomization}

One kidney from the pair was randomized in a 1:1 ratio and preserved with HOPE + MSC-derived EV (HOPE+EV study group) or with HOPE without MSC-derived EV (HOPE control group) after static cold storage (SCS) during transportation to the hospital. In both groups, the preservation was followed by perfusion with HBOCs. Randomization was carried out through Medidata Balance (New York, NY, USA) and was performed after the organ had been deemed unsuitable for transplantation.

\subsection{Ex Vivo Hypothermic Oxygenated Perfusion}

HOPE was performed using a VitaSmart ${ }^{\circledR}$ device designed for abdominal organ perfusion (Bridge to Life). The kidneys were connected to the perfusion device through sterile disposable tubes and the vessels were cannulated with a cannula specified for vascular size. HOPE was performed for $4 \mathrm{~h}$ using Belzer MPS ${ }^{\circledR} \mathrm{UW}$ Machine Perfusion Solution (Bridge to Life) at $4{ }^{\circ} \mathrm{C}$ through the artery with peristaltic flow at $25-30 \mathrm{mmHg}$ pressure. Flow, pressure, and temperature were monitored and registered automatically by the minute. Oxygen and carbon dioxide partial pressure (pO2 and $\mathrm{pCO} 2)$ and $\mathrm{pH}$ was monitored every $15 \mathrm{~min}$ in the effluent perfusate via blood gas analysis (GEM Premier 4000, Werfen, Italy).

\subsection{Ex Vivo Kidney Reperfusion with HBOCs}

After ex vivo kidney perfusion, the kidneys of both groups were reperfused in a model simulating transplant reperfusion. The organs were kept on ice until they were placed again on the reperfusion device. After that, they were perfused using HBOCs.

The circuit was primed with one unit of HBOCs; the organs were reperfused for $4 \mathrm{~h}$ at 20-25 ${ }^{\circ} \mathrm{C}$ and $60 \mathrm{mmHg}$ pressure through peristaltic flow with the same MP procedure. As in the perfusion phase, during ex vivo reperfusion, we monitored the flow, pressure, and 
temperature, which were registered automatically by the minute and every $15 \mathrm{~min}$ in the effluent perfusate via blood gas analysis (GEM Premier 4000).

The effluent perfusate was collected before and after the HMP and NMP to quantify the glucose and lactate concentrations via blood gas analysis (GEM Premier 4000).

Biopsy samples were collected after SCS and after both hypothermic and normothermic preservation. The kidney tissue was fixed in 10\% formalin for morphological and immunohistochemical studies and in $2.5 \%$ glutaraldehyde and cacodylate sodium buffer (pH 7.4) for ultrastructural analysis.

\subsection{MSC and EV Isolation and Characterization}

Bone marrow MSC were purchased from Lonza (Basel, Switzerland) and cultured in a MSC basal medium BulletKit (Lonza). The cells were used within the sixth passage and the typical mesenchymal markers were detected by cytofluorimetric analysis as de-scribed previously [49-52].

EV were obtained by ultracentrifugation $[50,51]$. Briefly, the EV were obtained from $24 \mathrm{~mL}$ of the supernatants of MSC cultured overnight in Roswell Park Memorial Institute (RPMI) 1640 medium. The cell debris and apoptotic bodies were removed by 20-min centrifugation at $3000 \times g$ and by microfiltration using a $0.22-\mathrm{mm}$ vacuum filter unit (Millipore, Billerica, MA, USA). EV were purified by 2-h ultracentrifugation at $100,000 \times g$ at $4{ }^{\circ} \mathrm{C}$ (Beckman Coulter Optima L-100 K, Fullerton, CA, USA). EV were used fresh or stored at $-80{ }^{\circ} \mathrm{C}$ after resuspension in RPMI 1640 medium supplemented with $1 \%$ dimethyl sulfoxide (Sigma, St. Louis, MO, USA).

EV were characterized using a human cytofluorimetric bead-based MACSPlex exosome kit (Miltenyi Biotec, Bergisch Gladbach, Germany) according to the manufacturer's proto-col [53]. EV were diluted in MACSPlex buffer (MPB) in the presence of the MACSPlex exosome capture beads. EV on the capture beads were counterstained by adding APCconjugated anti-CD9, anti-CD63, and anti-CD81 detection antibodies and were incubated for $1 \mathrm{~h}$ at room temperature in the dark on an orbital shaker at $450 \mathrm{rpm}$. Post-incubation, the beads were washed first with $1 \mathrm{~mL} \mathrm{MPB}$ at $3000 \times g$ for $5 \mathrm{~min}$, followed by a longer washing step by incubating the beads in $1 \mathrm{~mL} \mathrm{MPB}$ on an orbital shaker (as before) for $15 \mathrm{~min}$. Then, the beads were centrifuged at $3000 \times g$ for $5 \mathrm{~min}$ and the supernatant was carefully aspirated, leaving a residual volume of $150 \mathrm{~mL}$ per tube for acquisition. Flow cytometry was performed using a CytoFLEX flow cytometer (Beckman Coulter, Brea, CA, USA), where approximately 5000 single-bead events were recorded per sample. The median fluorescence intensity (MFI) for all 39 exosomal markers was corrected for background and gated based on their respective fluorescence intensity as per the manufacturer's instructions.

The concentration of the EV preparations was determined using a NanoSight LM10 instrument (NanoSight Ltd., Amesbury, UK) equipped with a $405 \mathrm{~nm}$ laser. The recordings of three 60-s videos were examined using nanoparticle tracking analysis (NTA version 3.4).

\subsection{Hemoglobin-Based Oxygen Carriers}

Glutathione-polymerized bovine hemoglobin $(\mathrm{bHb})$ was prepared using a modified version of published protocols [54]. Fresh bovine blood was collected, using EDTA as an anticoagulant $(1.5 \mathrm{mg} / \mathrm{mL}$ blood). The RBCs were recovered by 10 -min centrifugation at $15,000 \times g$ and washed three times by centrifugation/resuspension cycles with sterile isotonic saline solution $(0.9 \% \mathrm{NaCl})$. The cells were lysed with a PandaPlus 200 homogenizer $\left(\right.$ GEA $^{\circledR}$, Parma, Italy) for one cycle at 500 torr. Cell debris were removed by 1-h centrifugation at $10,000 \times g$ at $4{ }^{\circ} \mathrm{C}$. Oxygenated bHb was reacted with glutaraldehyde in a 1:10 molar ratio at $37^{\circ} \mathrm{C}$ for $3 \mathrm{~h}$ under continuous stirring. The reaction was quenched at $4{ }^{\circ} \mathrm{C}$ for 30 min with a two-fold molar excess of $\mathrm{NaBH}_{4}$ dissolved in $20 \mathrm{mM}$ phosphate-buffered saline (PBS), $\mathrm{pH}$ 8. Diafiltration through a sterile tangential flow filter was performed at $4{ }^{\circ} \mathrm{C}$ for $24 \mathrm{~h}$ to remove unreacted glutaraldehyde and to exchange the buffer to sterile Ringer's solution $\left(7.2 \mathrm{~g} / \mathrm{L} \mathrm{NaCl}, 0.017 \mathrm{~g} / \mathrm{L} \mathrm{CaCl}_{2}, \mathrm{KCl} 0.37 \mathrm{~g} / \mathrm{L}, \mathrm{pH} 7.4\right)$. The HBOC solution at a final concentration of $3.5 \mathrm{~g} / \mathrm{dL}$ was frozen and stored at $-80^{\circ} \mathrm{C}$. The oxygen binding 
parameters of the final preparation were measured using a tailor-made tonometer $[55,56]$ at $25^{\circ} \mathrm{C}$, the intended temperature of use. The polymerized $\mathrm{bHb}$ exhibited a $\mathrm{P} 50(\mathrm{Hb}$ oxygen affinity) of 8.2 torr and lost its binding cooperativity (Hill coefficient $=1.0$ ) as reported previously [57]. Oxidation to methemoglobin (met-Hb) was followed spectroscopically at every preparation step and after the perfusion experiments. No significant met- $\mathrm{Hb}$ formation was observed.

\subsection{Renal Morphology}

Five non-consecutive cross-sections of each kidney were stained with periodic acidSchiff (PAS) and examined by two investigators in double-blind fashion using a Nikon Eclipse E200 microscope (Amsterdam, the Netherlands) connected to a CCD (chargecoupled de-vice) camera and Image J imaging analysis software (NIH, Bethesda, MD, USA). Renal damage was assessed by scoring all tubules acquired in each high-powered field (HPF). We analyzed at least 10 non-consecutive fields. The tubular lesions analyzed were tubular epithelial cell flattening (TF), brush border loss (BBL), bleb formation (BF), tubular necrosis (TN), and tubular lumen obstruction (TO). TF and BBL were classified as mild lesions; $\mathrm{BF}, \mathrm{TN}$, and TO were severe lesions.

The global ischemic renal damage score as described by Paller et al. [14] was obtained by assigning each lesion a score: TF (1 point), BBL (1 point), BF ( 2 points), TN (2 points), and TO ( 2 points). When $\geq 2$ lesions were present in the same tubule, the most severe score was assigned.

\subsection{Transmission Electron Microscopy}

Transmission electron microscopy (TEM) was performed using a standard technique: kidney tissues from all groups were immediately fixed in $2.5 \%$ glutaraldehyde and cacodylate sodium buffer ( $\mathrm{pH} 7.4$ ) for $2 \mathrm{~h}$ at room temperature. Then, the samples were rinsed in cacodylate sodium buffer ( $\mathrm{pH} 7.4$ ) overnight and post-fixed in $1 \%$ aqueous osmium (OsO4) for $90 \mathrm{~min}$ at room temperature. The samples were dehydrated in increasing ethanol concentrations (50\% to $100 \%$ ). After polymerization with epoxy resin (Epon 812 ), the blocks were sectioned on a microtome (Leica, Wetzlar, Germany) to generate semithin sections. The sections were counterstained with toluidine blue for optical microscopy. Thin sections were double-stained with uranyl acetate and lead citrate. Observations and micrographs were performed on an electron microscope (Jeol JEM 1200, Tokyo, Japan) operating at $100 \mathrm{kV}$.

\subsection{Tubular Cell Proliferation Index and COX IV-1 Renal Expression}

The tubular cell proliferation index (IPT) was defined as the ratio between the nuclei ex-pressing proliferating cell nuclear antigen (PCNA) and the total nuclei in each tubule. The paraffin-embedded tissue sections were collected on poly-L-lysine-coated slides (Dako, Carpinteria, CA, USA), dewaxed in xylol, cleared in a decreasing series of alcohol, and re-hydrated with distilled water. Endogenous peroxidase was blocked with $\mathrm{H} 2 \mathrm{O} 2$ (3.7\% $\mathrm{vol} / \mathrm{vol}$ for PCNA and 3.0\% vol/vol for cytochrome c oxidase [COX] IV-1) followed by $\mathrm{H} 2 \mathrm{O}$ for $15 \mathrm{~min}$. After three washes in $150 \mathrm{mM}$ PBS, the sections underwent microwave antigen retrieval. Subsequently, they were exposed overnight at $4{ }^{\circ} \mathrm{C}$ to monoclonal mouse anti-PCNA antibody (1:200, Santa Cruz Biotechnology, Santa Cruz, CA, USA) or to COX IV-1 anti-human antibody (1:50, ABclonal, Woburn, MA, USA). After three washes in PBS, the immunocomplex was visualized with biotin-streptavidin-peroxidase complex and 3,3diaminobenzidine (Dako, Glostrup, Denmark). The sections were lightly counter-stained with Harris hematoxylin. Negative controls were established by omitting the primary antibody and substituting immunoglobulin $\mathrm{G}(\mathrm{IgG})$ for the primary antibodies.

Ten non-consecutive sections from each immunostained kidney were analyzed. The images were captured using a Nikon Eclipse E200 microscope connected to a CCD camera and ImageJ (NIH). 
The IPT was evaluated by counting the number of PCNA-positive nuclei/total nuclei of each tubule in every field analyzed $(\times 40)$.

COX IV-1 expression was assessed by converting the immunohistochemistry image to black and white and quantifying the pixel number $(\times 10)$. The results are shown as the percentage of black pixel numbers/total pixel numbers [58].

\subsection{HGF and VEGF Tissue Levels}

Human vascular endothelial growth factor (VEGF) and human hepatocyte growth factor (HGF) were evaluated using a commercial enzyme-linked immunosorbent assay kit (R\&D Systems, Minneapolis, MN, USA) following the manufacturer's instructions. The results are expressed as $\mathrm{pg} / \mathrm{mL}$.

\subsection{Apoptosis}

The dewaxed and rehydrated tissue sections were permeabilized by 5 -min incubation with PBS- $0.1 \%$ Triton X-100 at room temperature.

After washing in PBS, the sections were incubated with blocking buffer (PBS- $0.1 \%$ Tween $20+5 \%$ goat serum) in a humidified chamber for $2 \mathrm{~h}$ at room temperature. Then, the sections were washed again in PBS and incubated with primary antibody (1:200 dilution in blocking buffer, rabbit anti-caspase-3 antibody, active, C8487, Sigma) overnight in a humidified chamber at $4{ }^{\circ} \mathrm{C}$. The following day, the slides were incubated with $3.7 \% \mathrm{H} 2 \mathrm{O} 2$ for $15 \mathrm{~min}$ in a humidified chamber at room temperature to inhibit endogenous peroxidase. The secondary antibody was horseradish peroxidase-labeled polymer conjugated to goat anti-rabbit antibody (EnVision + System (DAB), DAKO North America, Carpinteria, CA, USA). The immunocomplex was visualized with 3,3-diaminobenzidine (Dako, Glostrup, Denmark). The sections were lightly counterstained with Harris hematoxylin. Negative controls were established by omitting the primary antibody and substituting IgG for the primary antibodies.

Ten non-consecutive sections of each immunostained kidney were analyzed. The images were captured using a Nikon Eclipse E200 microscope connected to a CCD camera and ImageJ (NIH).

Apoptosis was evaluated by counting the number of caspase-3-positive cells in every $\mathrm{HPF}$ analyzed $(\times 40)$.

\subsection{Statistical Analysis}

GraphPad Prism software (San Diego, CA, USA) was used for the statistical analyses. Data are expressed as the mean and standard deviation or the median and interquartile range (IQR) or as the minimum (min) and maximus (max) in accordance with the data distribution. Parametric and non-parametric variables among the two groups were compared using Student's unpaired t-test or the Mann-Whitney test. Continuous and noncontinuous variables among $>2$ groups were compared using analysis of variance (ANOVA) or Kruskal-Wallis test as appropriate followed by the Tukey test and Dunn's multiple comparisons test, respectively. A $p$-value $<0.05$ was considered statistically significant.

\section{Results}

\subsection{Donor Characteristics}

Table 1 shows the donor characteristics: age, sex, weight, height, body mass index (BMI), blood group, cause of death, type of donation, histological Remuzzi score of kidneys en-rolled in the study, and duration of SCS before hypothermic perfusion. Ten kidneys from five ECD were included in the study. Five kidneys were perfused with HOPE (HOPE) and the other ones with $\mathrm{EV}(\mathrm{HOPE}+\mathrm{EV})$. Subsequently all kidneys were reperfused with HBOCs (NR HOPE $n=5$; NR HOPE +EV $n=5$ ). 
Table 1. Donors and kidney characteristics.

\begin{tabular}{cccccc}
\hline & Donor 1 & Donor 2 & Donor 3 & Donor 4 & Donor 5 \\
\hline Age & 72 & 72 & 80 & 81 & 81 \\
\hline Sex & $\mathrm{F}$ & $\mathrm{F}$ & $\mathrm{M}$ & $\mathrm{F}$ & $\mathrm{F}$ \\
\hline Weight $(\mathrm{kg})$ & 90 & 72 & 85 & 80 & 80 \\
\hline Height $(\mathrm{cm})$ & 1.55 & 1.60 & 1.75 & 1.50 & 1.50 \\
\hline BMI $\left(\mathrm{kg} / \mathrm{cm}^{2}\right)$ & 37.50 & 28.10 & 27.80 & 35.60 & 35.60 \\
\hline Blood group & $\mathrm{A}$ & 0 & $\mathrm{~A}$ & $\mathrm{~A}$ & 0 \\
\hline RH BG & Pos & Pos & Pos & Pos & Neg \\
\hline Cause of death & $\mathrm{ch}$ & $\mathrm{ch}$ & $\mathrm{ch}$ & is & ch \\
\hline Score $\boldsymbol{R}$ kidney & 6 & 8 & 7 & 6 & 8 \\
\hline Score L kidney & 6 & 7 & 8 & 7 & 7 \\
\hline Donor type & DBD & DBD & DBD & DBD & DBD \\
\hline SCS $(\mathrm{h})$ & 17 & 37 & 32 & 22 & 16
\end{tabular}

BMI, body mass index; BG, blood group; R, right; L, left; ch, cerebral hemorrhage; is, ischemic stroke; DBD, donor after brain death; SCS, static cold storage; $h$, hours.

\subsection{EV Characterization}

Cytofluorimetric analysis revealed that the EV were positive for the typical MSC markers such as CD29, CD44, CD49e, CD105, CD146, and for the exosomal tetraspanins $\mathrm{CD} 9, \mathrm{CD} 63$, and CD81, but did not express hematopoietic (CD45, CD3, CD8), endothelial (CD31), or epithelial (CD24 and CD326) markers (Figure S1) as previously reported (53). NTA revealed that the EV size was in the typical range of 30-300 nm (Figure S1). We used $28.5 \times 10^{9} \mathrm{EVs}$ to treat the perfused kidney

\subsection{Perfusion Parameters}

The perfusion parameters did not differ between the groups during HMP and NR (Table 2). The perfusion and reperfusion phases were performed without complications. The solutions containing the EV and HBCOs did not affect the perfusion parameters.

Table 2. Perfusion parameters.

\begin{tabular}{|c|c|c|c|c|c|c|}
\hline Time & $\begin{array}{c}\text { Variables } \\
\text { Media +/-SD }\end{array}$ & HOPE & HOPE+EV & NR HOPE & $\begin{array}{c}\text { NR } \\
\text { HOPE+EV }\end{array}$ & $\begin{array}{c}p \\
\text { Value }\end{array}$ \\
\hline \multirow{2}{*}{ T0 } & $\begin{array}{c}\text { Flow } \\
(\mathrm{ml} / \mathrm{min})\end{array}$ & $\begin{array}{c}67.0 \\
+/-51.2\end{array}$ & $\begin{array}{c}64.4 \\
+/-41.9\end{array}$ & $\begin{aligned} & 141.8 \\
&+/-61.3\end{aligned}$ & $\begin{array}{c}163.0 \\
+/-36.3\end{array}$ & NS \\
\hline & $\begin{array}{c}\text { Resistances } \\
(\mathrm{mmHg} \mathrm{min} / \mathrm{ml})\end{array}$ & $\begin{array}{c}0.36 \\
+/-0.26 \\
\end{array}$ & $\begin{array}{c}0.39 \\
+/-0.12 \\
\end{array}$ & $\begin{array}{c}0.29 \\
+/-0.18 \\
\end{array}$ & $\begin{array}{c}0.29 \\
+/-0.04 \\
\end{array}$ & NS \\
\hline \multirow{2}{*}{ Tend } & $\begin{array}{c}\text { Flow } \\
(\mathrm{ml} / \mathrm{min})\end{array}$ & $\begin{array}{r}68.3 \\
+/-30.4 \\
\end{array}$ & $\begin{array}{c}62.2 \\
+/-24.7 \\
\end{array}$ & $\begin{aligned} & 183.0 \\
&+/-71.3 \\
&\end{aligned}$ & $\begin{array}{r}183.3 \\
+/-36.9 \\
\end{array}$ & NS \\
\hline & $\begin{array}{c}\text { Resistances } \\
(\mathrm{mmHg} \mathrm{min} / \mathrm{ml})\end{array}$ & $\begin{array}{c}0.31 \\
+/-0.13\end{array}$ & $\begin{array}{c}0.38 \\
+/-0.12\end{array}$ & $\begin{array}{c}0.25 \\
+/-0.13\end{array}$ & $\begin{array}{c}0.23 \\
+/-0.04\end{array}$ & NS \\
\hline
\end{tabular}

T0, time at the beginning of HOPE or NR HOPE with and without EV. Tend, time at the end of HOPE or NR HOPE with and without EV.

\subsection{Global Renal Ischemic Damage Score}

The global ischemic renal damage score was significantly more severe in SCS-preserved ECD kidneys (median, 70; range, 41-99) than in HOPE- (median, 40; range, 20-60) or HOPE+EV-preserved kidneys (median, 24; range, 21-36) $(p<0.001)$. Tubular epithelial cell flattening, blebs, tubular necrosis, and lumen obstruction were more frequent in HOPE than in HOPE+EV kidneys (Figure 2). 

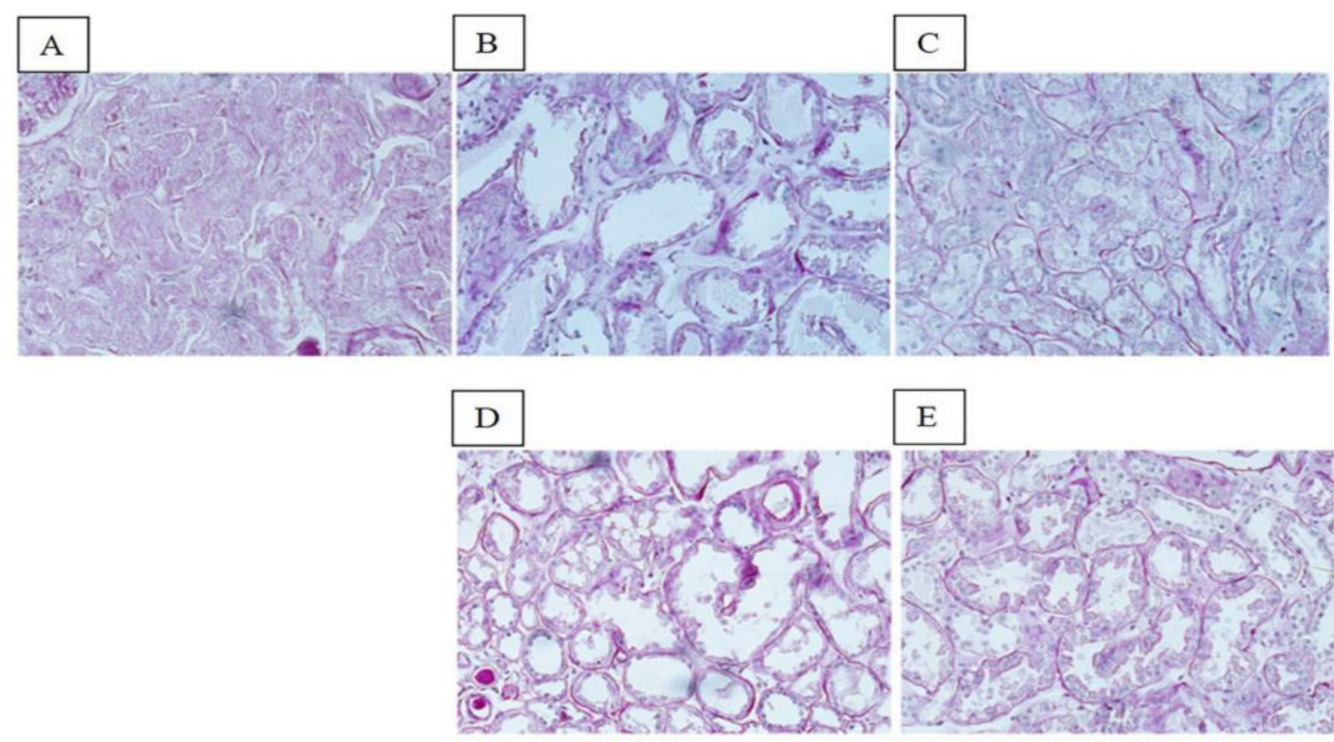

Figure 2. Renal morphology. PAS staining of representative renal sections from the SCS group (A), HOPE group (B), HOPE+EV group (C), NR HOPE group (D), and NR HOPE+EV group (E). $\times 20$ magnification.

\subsection{Ultrastructural Analysis}

Figure 3 shows the representative TEM renal sections of all groups. The SCS group had loss of normal cell architecture, cell shrinkage and necrosis, and dysmorphic and swollen mitochondria with loss and distortion of cristae. The HOPE group had partial loss of cell architecture and the mitochondria appeared spheroidal and elongated. In contrast, the HOPE+EV group had significantly reduced damage: the cell architecture and mitochondrial morphology were well preserved and the nucleus and basal membrane were normal. After $\mathrm{NR}$, the HOPE group had cytoplasmic vacuolization and brush borders with short, spaced microvilli, while the HOPE+EV group had cells with normal morphology and organelles, and interestingly, a long, preserved brush border.

\subsection{COX IV-1 Renal Expression}

To evaluate mitochondrial distress, we analyzed COX IV-1 renal expression. COX IV-1 renal expression was higher in HOPE+EV kidneys than in HOPE kidneys. COX IV-1 renal expression was highest in the NR HOPE+EV group $(p<0.0001)$ (Figure 4$)$. 


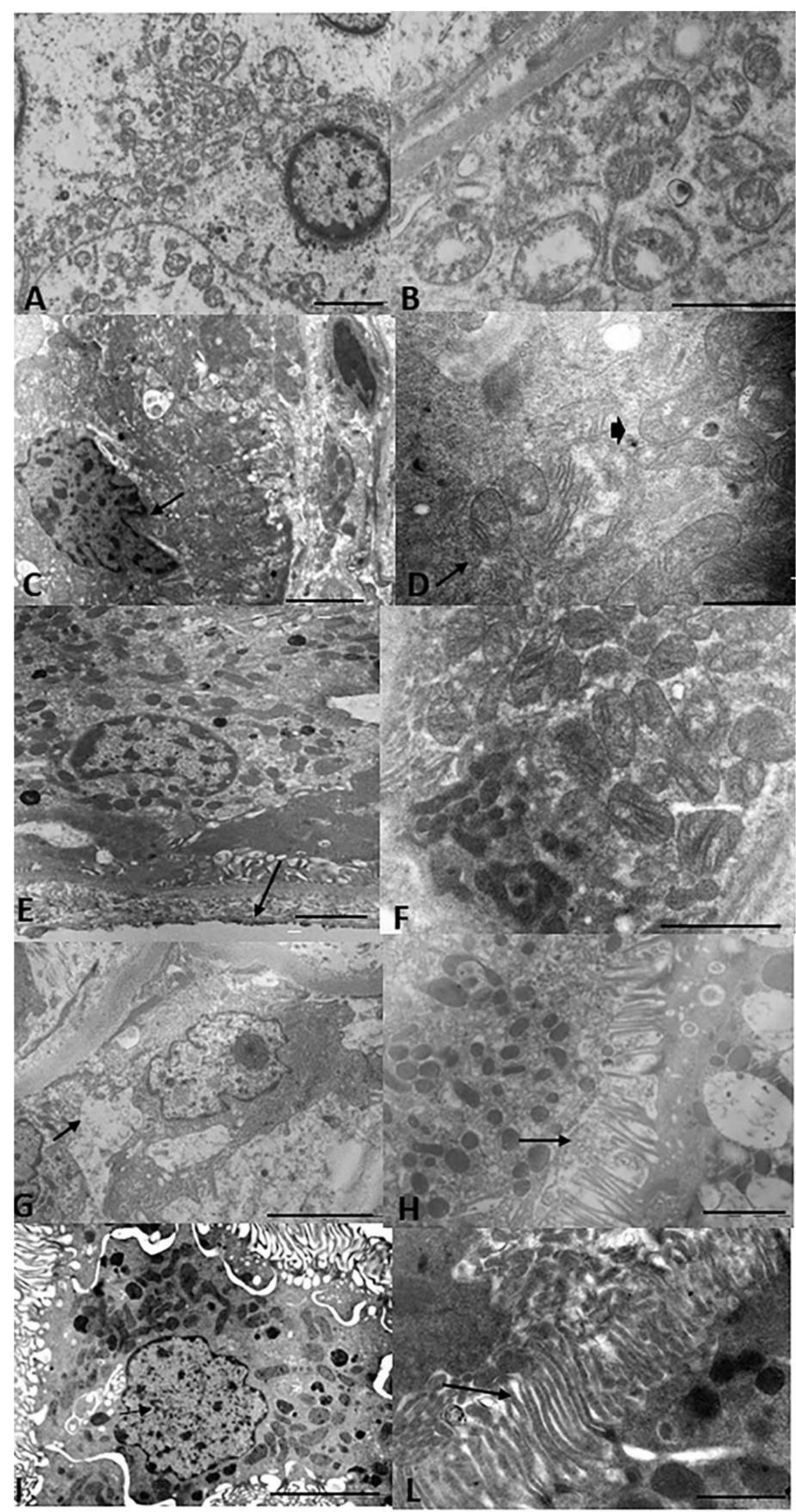

Figure 3. Renal ultrastructure. Representative TEM renal sections of all groups. (A) SCS kidney sections showing loss of normal cell architecture, cell shrinkage and necrosis, and thickened chromatin on the nuclear membrane. Bar $=2 \mu \mathrm{m}$. (B) At greater magnification, dysmorphic and swollen mitochondria with loss or distortion of cristae can be seen. Bar $=2 \mu \mathrm{m}$. (C) HOPE kidney sections showing partial loss of cell architecture and nuclear membrane invagination. Bar $=2 \mu \mathrm{m}$. (D) At greater magnification: spheroidal (arrow) and elongated (arrowhead) mitochondria can be seen. Bar $=5 \mu \mathrm{m}$. (E) HOPE+EV kidney sections showing well-preserved cell architecture, normal nucleus and basal membrane, and numerous basal micropedici (arrow). Bar $=2 \mu \mathrm{m}$. (F) Higher magnification showing that normal morphology of the mitochondria and cristae was well preserved. Bar $=2 \mu \mathrm{m}$. (G) NR HOPE kidney sections showing cytoplasmic vacuolization (arrow). Bar $=5 \mu \mathrm{m}$. (H) At greater magnification, brush borders with short and spaced microvilli (arrow) can be seen. Bar $=2 \mu \mathrm{m}$. (I) NR $\mathrm{HOPE}+\mathrm{EV}$ sections showing cells with normal morphology and organelles. Bar $=5 \mu \mathrm{m}$. (L) At greater magnification, a long, preserved brush border can be seen. Bar $=2 \mu \mathrm{m}$. 

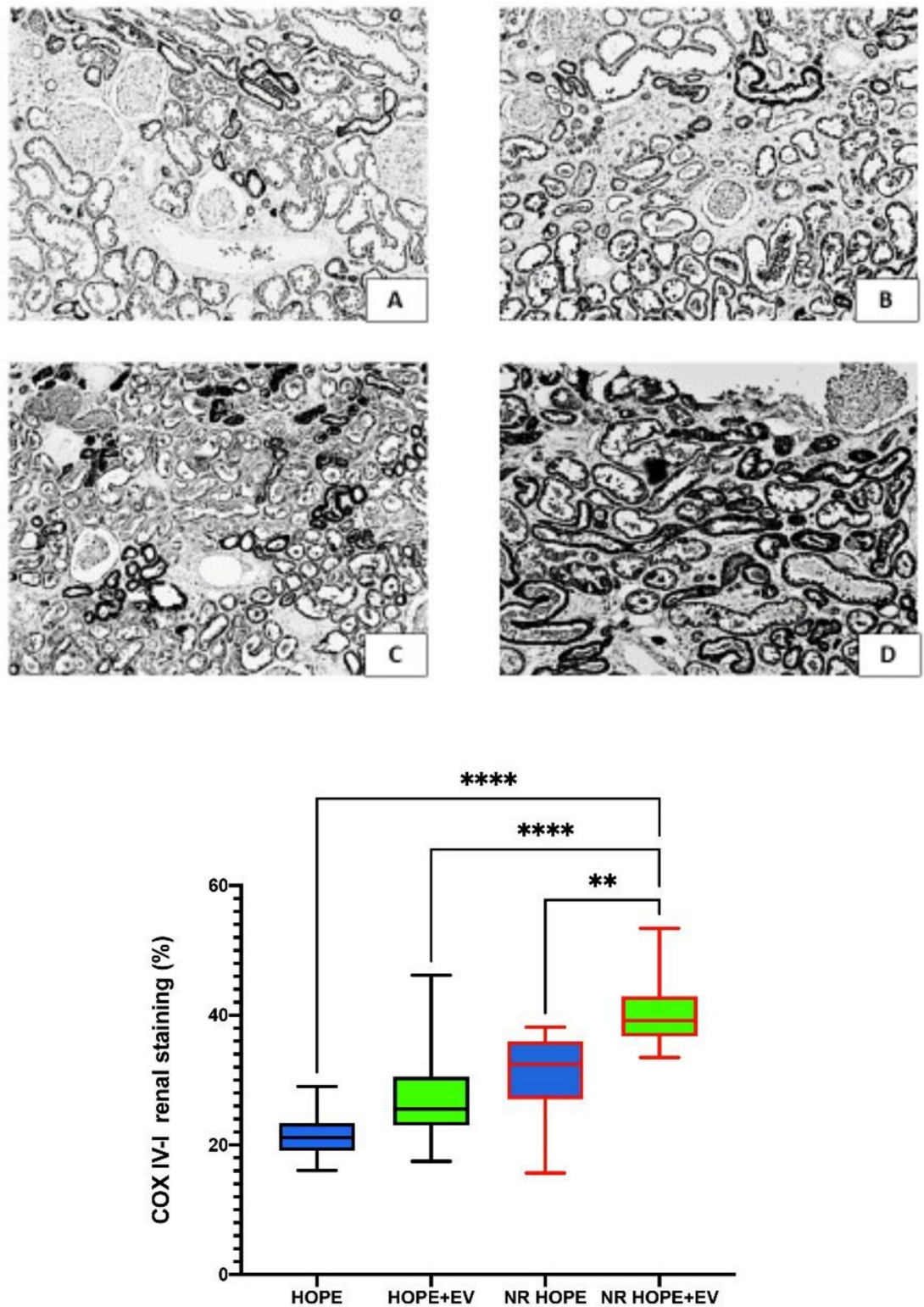

Figure 4. COX IV-1 renal expression. Top: Representative renal sections of COX IV-1 staining in the HOPE group (A), HOPE+EV group (B), NR-HOPE group (C), and NR-HOPE+EV group (D). $\times 20$ magnification. Bottom: Columns represent COX IV-1 positive staining percentage in all groups. Data are the median and IQR, or min and max. (NR HOPE+EV vs. HOPE and HOPE+EV **** $p<0.0001$; vs. NR HOPE ${ }^{* *} p<0.005$ ).

\subsection{Caspase-3 Renal Expression}

To evaluate apoptosis, we examined caspase-3, a crucial mediator of programmed cell death. Caspase-3 renal expression was higher in the HOPE groups than in the HOPE+EV groups $(p<0.001)$ (Figure 5A). 

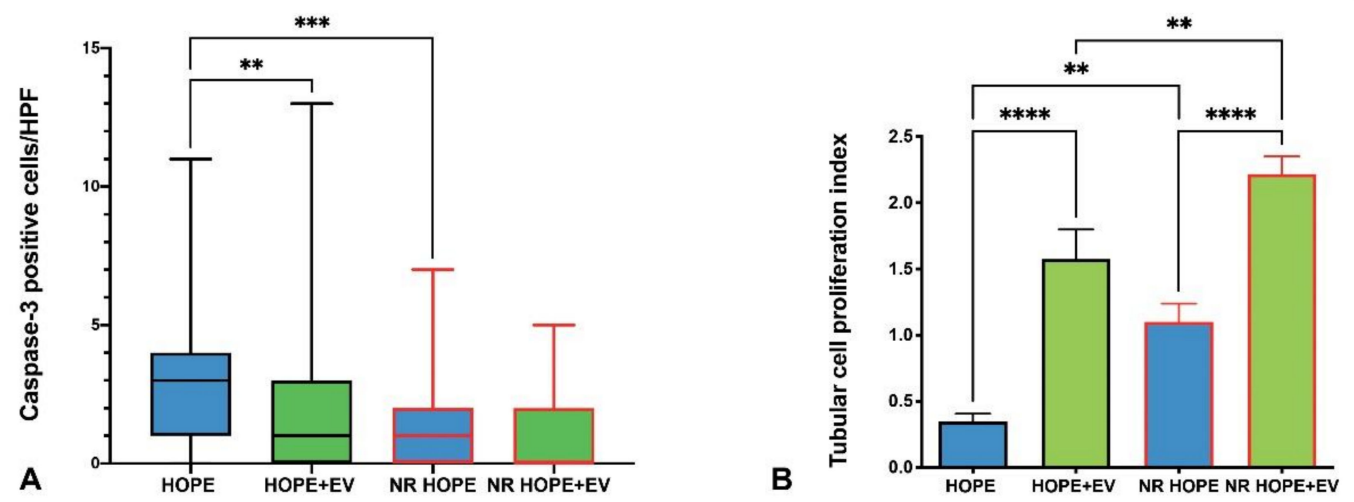

Figure 5. (A) Caspase-3 renal expression: columns represent caspase-3-positive cells/HPF in all groups. Data are represented as median and IQR (boxes), and min and max (whiskers). ${ }^{* *} p<0.05$ vs. HOPE, ${ }^{* * *} p<0.001$ vs. HOPE. (B) Tubular cell proliferation index: the number of PCNApositive nuclei/total nuclei of each tubule was lower in the HOPE and NR HOPE groups than in the $\mathrm{HOPE}+\mathrm{EV}$ and NR HOPE+EV groups (ANOVA, $p<0.0001$; Tukey Multiple Comparison Test, HOPE vs. $\mathrm{HOPE}+\mathrm{EV}^{* * * *} p<0.0001$ and vs. NR HOPE ${ }^{* *} p<0.005 ; \mathrm{HOPE}+\mathrm{EV}$ vs. NR HOPE+EV $p<0.001$; NR HOPE vs. NR HOPE+EV $p<0.0001)$.

\subsection{Tubular Cell Proliferation Index}

To evaluate tissue viability, we studied tubular cell proliferation. The IPT after NMP and HMP was higher in the HOPE+EV groups than in the HOPE groups $(p<0.0001)$ (Figure 5B).

\subsection{HGF and VEGF Tissue Levels}

The NR HOPE+EV group had increased renal tissue levels of the growth factors HGF and VEGF (HGF: median, 5.85 pg/mL; range, 2.56-9.15; VEGF: median, 1.95 pg/mL; range, 0.83-3.13) compared to the NR HOPE group (HGF: median, $0.86 \mathrm{pg} / \mathrm{mL}$; range, 0.33-1.4; VEGF: median, $0.30 \mathrm{pg} / \mathrm{mL}$; range, $0.05-0.78, p<0.001)$.

\subsection{Lactate and Glucose Levels in Effluent Fluid}

To evaluate tissue performance, we measured the main intermediators of energy metabolism in the effluent: lactate and glucose.

At the end of the HOPE the lactate levels significantly increased $(p<0.05)$ and glucose levels decreased in the effluent of both groups, suggesting the conversion of glucose, provided by the Belzer solution, to lactate as in anaerobic glycolysis (Table 3).

Table 3. Lactate and glucose concentrations in effluent fluid at the beginning and end of HOPE with and without EV.

\begin{tabular}{|c|c|c|c|c|c|}
\hline \multirow{2}{*}{$\begin{array}{c}\text { Variables } \\
\text { (Media; SD) }\end{array}$} & \multicolumn{2}{|c|}{ HOPE } & \multicolumn{2}{|c|}{ HOPE+EV } & \multirow{2}{*}{$p$ Value } \\
\hline & T0 & Tend & T0 & Tend & \\
\hline $\begin{array}{c}\text { Lactate } \\
(\mathrm{mmol} / \mathrm{dL})\end{array}$ & $\begin{array}{c}0.7 \\
(0.2)\end{array}$ & $\begin{array}{l}1.4 * \\
(0.5)\end{array}$ & $\begin{array}{c}0.6 \\
(0.2)\end{array}$ & $\begin{array}{l}1.9^{\circ} \\
(0.5)\end{array}$ & $\begin{array}{c}<0.05 \\
\text { * vs T0 HOPE } \\
{ }^{\circ} \text { vs T0 HOPE+EV }\end{array}$ \\
\hline $\begin{array}{l}\text { Glucose } \\
\text { (mg/dL) }\end{array}$ & $\begin{array}{l}174.3 \\
(4.5)\end{array}$ & $\begin{array}{l}165.8 \\
(6.9)\end{array}$ & $\begin{array}{l}184.4 \\
(9.6)\end{array}$ & $\begin{array}{c}170.2^{\S} \\
(4.9)\end{array}$ & $\begin{array}{c}<0.05 \\
\S_{\text {vs T0 HOPE }+ \text { EV }}\end{array}$ \\
\hline
\end{tabular}

${ }^{*} p<0.05$ vs. T0 HOPE, ${ }^{\circ} p<0.05$ vs. T0 HOPE + EV; ${ }^{\S} p<0.05$ vs. T0 HOPE+EV.

During NR, we observed lower lactate release in the HOPE+EV effluent than in the HOPE effluent. In parallel, the HOPE+EV group had increased effluent glucose levels than the HOPE group (expressed as the Tend/T0 ratio). As glucose was not provided by the HBOC solution during the normothermic reperfusion, the higher glucose levels indicate 
that it was synthesized by the renal tissue, suggesting that the gluconeogenesis system was well preserved (Figure 6).

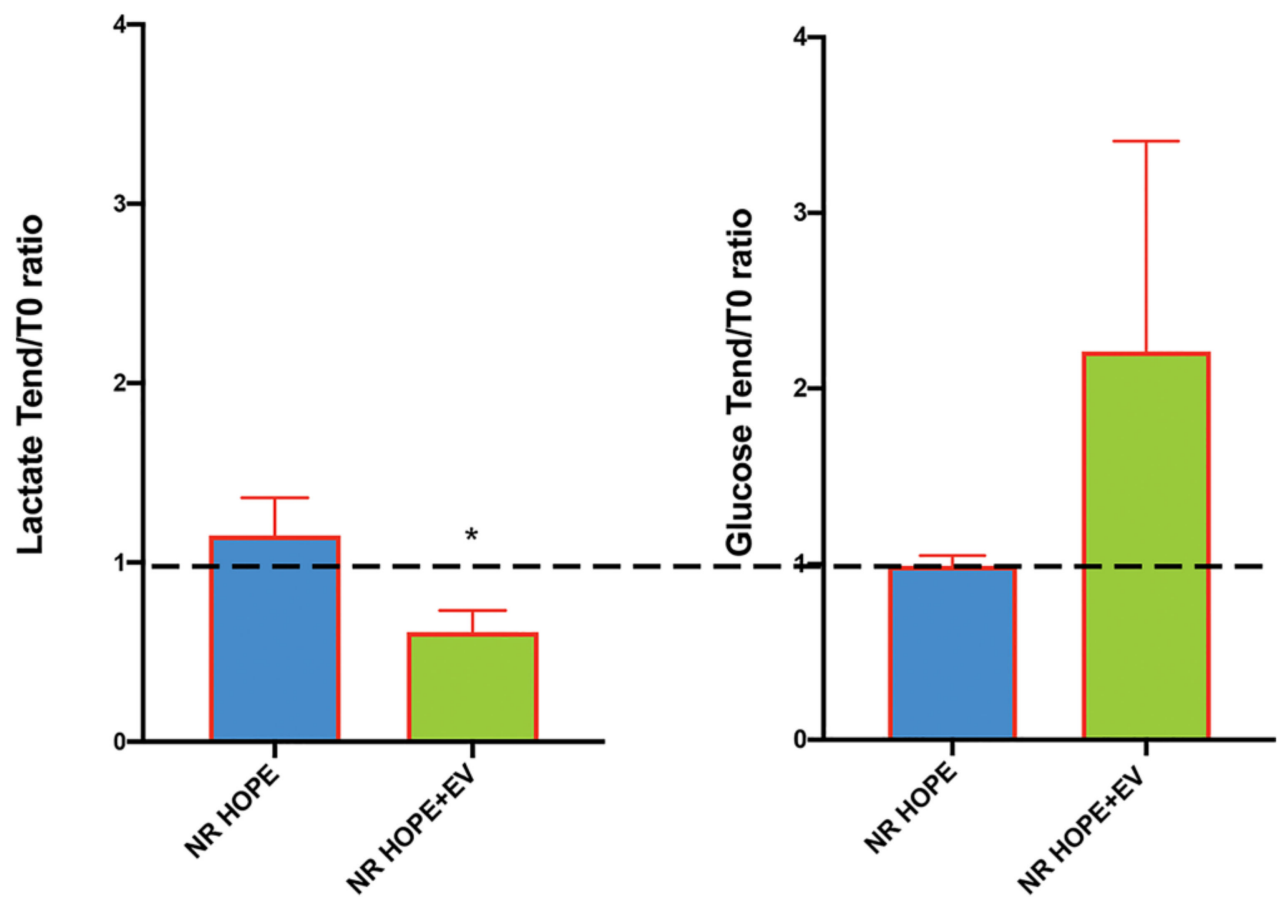

Figure 6. Effluent lactate and glucose levels in all groups at the beginning and end of HOPE and NR HOPE with or without EV, expressed as the Tend/T0 ratio. ${ }^{*} p<0.05$ vs. NR HOPE.

\section{Discussion}

Organ conditioning before transplantation is a technique with great potential by virtue of its ability to transfer drugs and buffer to the tissue. Here, we report the results of an innovative and pioneering EV delivery system for human kidney preservation in organs discarded due to high chronic damage scores. EV have recently gained interest for drug delivery purposes since they offer many advantages, such as high permeability, low immunogenicity, and non-cytotoxicity [59-61]. Moreover, among the different regenerative medicine strategies, EV have been recognized as a promising and innovative tool for accelerating tissue recovery after organ damage. They improve graft survival due to their ability to transfer to damaged cells proteins, bioactive lipids, microRNAs, mRNAs, and growth factors, which exert proliferative, anti-fibrotic, and immunomodulatory effects [62-67].

Here, we used an original ex vivo IRI model where ECD organs were perfused with MSC-derived EV delivered during HOPE, and re-perfused with a solution containing HBOCs.

EV delivery during HOPE significantly improved organ quality even though the kidneys were organs discarded for transplantation due to their high chronic histological score.

The switch from aerobic to anaerobic metabolism induced by prolonged ischemia leads to intracellular changes and architecture subversion. We observed the typical morphological changes such as brush border loss, bleb formation, tubular epithelial cell flattening, tubular necrosis, and tubular lumen obstruction in all groups. The HOPE+EV kidneys had significantly lower global renal damage score and better-preserved tissue ultra-structure than the HOPE and SCS kidneys. To evaluate the effect on oxygen-induced renal damage, we used a solution containing HBOCs lacking the immune/inflammatory cellular components of blood.

HBOCs are based on cell-free $\mathrm{Hb}$ subjected to either chemical or genetic modifications to increase retention in the bloodstream while maintaining oxygen delivery to tissues $[35,56,68,69]$. They include conjugated, crosslinked, polymerized, encapsulated $\mathrm{Hb}$ of either human or animal origin [70-81]. Depending on the preparation protocol, they may 
exhibit various biochemical and biophysical properties [82] that can be finely regulated to achieve the optimal product for specific applications. Unlike RBCs, HBOCs can be used at different temperatures, their properties can be finely regulated, they do not need blood typing, and they can be stored for much longer times either as a solution or frozen, i.e., all important advantages for the experimenter. Using a rat model, we have previously demonstrated that EV delivered during organ hypothermic perfusion protected the kidney from ischemic injury [38], but we did not study the NR phase.

Under ischemia/reperfusion, hypoxia and oxidative stress lead to the overproduction of mitochondrial ROS, Ca2+ overload, and prolonged mitochondrial permeability transition pore (mPTP) opening that forms a channel to release cytochrome $\mathrm{c}$ into the cytoplasm and then activate the apoptosis cascade $[83,84]$. COX is a multi-subunit enzyme complex that couples the transfer of electrons from cytochrome $\mathrm{c}$ to molecular oxygen and contributes to a proton electrochemical gradient across the inner mitochondrial membrane. The complex consists of 13 mitochondrial- and nuclear-encoded subunits. The COX IV-1 sub-unit is a component of COX, the last enzyme in the mitochondrial electron transport chain, which drives oxidative phosphorylation. COX IV-1 degradation is induced in cells exposed to hypoxia [85]. Here, NR HOPE kidneys had lower renal COX IV-1 expression than NR $\mathrm{HOPE}+\mathrm{EV}$ kidneys at the end of NR, suggesting that HOPE+EV preservation is more protective against IRI damage to the mitochondrial structure. This mitochondrial dysfunction is also accompanied by structural remodeling and morphological shape changes (mitochondrial spheroids). Using TEM, we confirmed that the HOPE and SCS kidneys had subverted cell architecture and more mitochondrial spheroids compared with the HOPE+EV and NR HOPE+EV kidneys (Figure 3). The mitochondria can mediate cell death through the release of proapoptotic proteins. In particular, once cytochrome $\mathrm{c}$ is translocated to the cytosol, it binds to the APAF-1 protein, which then triggers the activation of the caspase cascade [86]. Accordingly, we investigated caspase expression in renal tissue and observed significantly fewer apoptotic nuclei in HOPE+EV kidneys than in HOPE kidneys, confirming the known protective effect of EV against apoptosis [67,87].

The greater viability of the EV-conditioned kidneys was also demonstrated by the higher IPT in the HOPE+EV kidneys and even more in the NR HOPE+EV kidneys than in HOPE kidneys. In parallel, VEGF and HGF tissue levels were higher in the NR HOPE+EV group than in the NR HOPE group, confirming that the EV regenerative effect may be mediated by the release of HGF and VEGF $[41,45,67,88]$.

Finally, the analysis of the principal intermediaries in energetic metabolism in the effluents of the perfused kidneys confirmed the beneficial effects of EV on organ viability. During hypothermic perfusion, the ischemic damage marker, lactate, was significantly increased, while glucose levels were significantly decreased. This suggested the conversion of glucose, provided by the Belzer solution, to lactate as in anaerobic glycolysis. In contrast, the glucose levels increased in $\mathrm{HOPE}+\mathrm{EV}$ during normothermic reperfusion, suggesting that the kidneys have the ability to synthesize glucose through gluconeogenesis, and this can occur since the tissue is well preserved and vital.

On the other hand, the main substrate for renal gluconeogenesis is lactate. Lactate uptake from the tubular lumen occurs through a carrier involving sodium-coupled monocarboxylate transporters (MCTs) expressed by the basolateral side of the tubular proximal cells. Previously, we demonstrated that MCT genes were up-regulated by EV in per-fused rat ischemic kidney [89]. Therefore, our results add another so far unknown and important piece to understanding the effects of EV on ischemic tissue.

In addition, our data show that IRI damage decreased after normothermic reperfusion with HBOCs, which is in contrast with the well-known adverse effects described for HBOC use in vivo (i.e., vasoconstriction, hypertension [90], and oxidative stress [91-94]). These results have led to disappointing clinical trials [95]. More recently, however, HBOCs have been repurposed as ex vivo perfusion solutions for their capability of providing oxy-gen to isolated organs, a key requirement in NMP technologies [96]. Moreover, although whole blood-based perfusates were initially shown to yield superior preservation of my- 
ocardial function in heart ex vivo perfusion in comparison to HBOCs [97], several NMP experiments have shown that HBOCs yield similar, if not better, results in comparison to RBCs in the liver [36,98-100] and kidney [37,101-103]. In our model, we could not distinguish the contribution from HBOCs and that induced by EV and/or HOPE. Nevertheless, the combined effects are certainly surprising. Some studies affirm that EV effects are temperature-dependent and that low temperatures reduce EV endocytosis by cells [104]. In contrast, in vitro experiments have demonstrated that MSC induce a proliferative effect on tubular epithelial cells even at low temperatures. We confirm here that EV can also act in hypothermia conditions [38].

\section{Conclusions}

In conclusion, in this study we explored an innovative tool for organ preservation aimed at preventing IRI damage in vulnerable marginal kidneys. We demonstrate that EV delivery during HOPE significantly reduces IRI damage in ECD kidneys. Therefore, it can be considered a new organ preservation strategy for increasing the donor pool and improving transplant outcomes. To the best of our knowledge, this is the first report on conditioning human kidneys with MSC-derived EV. Even though the ex vivo model study is limited, as the treated kidneys were not transplanted, we strongly believe that our results may form the basis for future randomized clinical trials.

Supplementary Materials: The following supporting information can be downloaded at: https:// www.mdpi.com/article/10.3390/biology11030350/s1, Figure S1: Characterization of EVs.

Author Contributions: T.R. designed the study, contributed to the analysis and interpretation of the results, she wrote the manuscript and approved the final version. M.G. designed the study, performed histological studies, statistical analysis and contributed to the interpretation of the results and to the writing of the manuscript. G.G. performed surgical experiments, contributed to collection and analysis of data, to the writing of the manuscript and to the design of the figures. E.F.P. and F.E. contributed to the collection and analysis of data. M.A.G. contributed to the histological studies, collection and analysis of data, to the writing of the manuscript and design of the figures and preparation of the final manuscript. S.B. (Stefano Bruno) performed the polymerized bovine hemoglobin artificial blood production and contributed to the writing of the manuscript. E.A. and S.B. (Stefano Bettati) performed the production of polymerized bovine hemoglobin artificial blood. A.A. performed the transmission electron micro-scope analysis and figures design. M.R. (Marina Ramus) contributed to the histological studies, collection and analysis of data. M.D.A. and G.T. performed the biochemical analysis. S.B. (Stefania Bruno) performed EV isolation and characterization, revised and approved the final version of the manuscript. G.C. performed the histological techniques. N.S. and F.B. contributed to the histological studies and performed the apoptosis assay. C.L. and V.S. approved the final version of the manuscript. F.O. and L.M. performed the surgery experiments. F.V. performed and supervised the surgery experiments. G.L.M. approved the final version of the manuscript. M.R. (Matteo Ravaioli) designed the study, performed and supervised the surgery experiments, contributed to the writing of the manuscript and approved the final version. All authors discussed the results and commented on the manuscript. All authors have read and agreed to the published version of the manuscript.

Funding: This research was funded by National Health System Research (RF-2016-02364732, Bando Ricerca Finalizzata 2016, Ministero della Salute-Rome, Italy).

Institutional Review Board Statement: This study was performed at the General Surgery and Transplant Unit of the IRCCS, Azienda Ospedaliero-Universitaria of Bologna in accordance with the Helsinki Declaration. All experimental procedures were approved by the Ethics in Research Committee in June 2016. The study underwent clinical trial registration (ClinicalTrials.gov ID: NCT03837197).

Informed Consent Statement: Not applicable.

Data Availability Statement: Part of the data presented in this study are available in the Supplementary Material. The remaining data presented in this study are available upon reasonable request from the corresponding author.

Conflicts of Interest: The authors declare no conflict of interest. 


\section{References}

1. Gregorini, M.; Maccario, R.; Avanzini, M.A.; Corradetti, V.; Moretta, A.; Libetta, C.; Esposito, P.; Bosio, F.; Dal Canton, A.; Rampino, T. Antineutrophil cytoplasmic anti-body-associated renal vasculitis treated with autologous mesenchymal stromal cells: Evaluation of the contribution of im-mune-mediated mechanisms. Mayo Clin. Proc. 2013, 88, 1174-1179. [CrossRef] [PubMed]

2. Bedino, G.; Esposito, P.; Bosio, F.; Corradetti, V.; Valsania, T.; Rocca, C.; Pattonieri, E.F.; Gregorini, M.; Rampino, T.; Dal Canton, A. The role of therapeutic drug monitoring in the treat-ment of cytomegalovirus disease in kidney transplantation. Int. Urol. Nephrol. 2013, 45, 1809-1813. [CrossRef] [PubMed]

3. Gregorini, M.; Corradetti, V.; Rocca, C.; Pattonieri, E.F.; Valsania, T.; Milanesi, S.; Serpieri, N.; Bedino, G.; Esposito, P.; Libetta, C.; et al. Mesenchymal Stromal Cells Prevent Renal Fibrosis in a Rat Model of Unilateral Ureteral Obstruction by Suppressing the Renin-Angiotensin System via HuR. PLoS ONE 2016, 11, e0148542.

4. Hart, A.; Smith, J.M.; Skeans, M.A.; Gustafson, S.K.; Wilk, A.R.; Castro, S.; Foutz, J.; Wainright, J.L.; Snyder, J.J.; Kasiske, B.L.; et al. OPTN/SRTR 2018 Annual Data Report: Kidney. Am. J. Transplant. 2020, 20 (Suppl. S1), 20-130. [CrossRef]

5. Metzger, R.A.; Delmonico, F.L.; FFeng, S.; Port, F.K.; Wynn, J.J.; Merion, R.M. Expanded criteria donors for kidney transplantation. Am. J. Transplant. 2003, 3, 114-125. [CrossRef]

6. La Manna, G.; Comai, G.; Cappuccilli, M.L.; Liviano D’Arcangelo, G.; Fabbrizio, B.; Valentini, C.; Carretta, E.; Ravaioli, M.; Scolari, M.P.; Ridolfi, L.; et al. Prediction of three-year out-come of renal transplantation from optimal donors versus expanded criteria donors. Am. J. Nephrol. 2013, 37, 158-166. [CrossRef] [PubMed]

7. Perico, N.; Cattaneo, D.; Sayegh, M.H.; Remuzzi, G. Delayed graft function in kidney transplantation. Lancet 2004, 364, $1814-1827$. [CrossRef]

8. Querard, A.-H.; Foucher, Y.; Combescure, C.; Dantan, E.; Larmet, D.; Lorent, M.; Pouteau, L.M.; Giral, M.; Gillaizeau, F. Comparison of survival outcomes between Expanded Criteria Donor and Standard Criteria Donor kidney transplant recipients: A systematic review and meta-analysis. Transpl. Int. 2016, 29, 403-415. [CrossRef]

9. Głyda, M.; Włodarczyk, Z.; Czapiewski, W. Results of renal transplantation from expanded criteria deceased donors-A sin-gle-center experience. Ann. Transplant. 2012, 17, 35-42.

10. Ojo, A.O.; Hanson, J.A.; Meier-Kriesche, H.-U.; Okechukwu, C.N.; Wolfe, R.A.; Leichtman, A.B.; Agodoa, L.Y.; Kaplan, B.; Port, F.K. Survival in recipients of marginal cadaveric donor kidneys compared with other recipients and wait-listed transplant candidates. J. Am. Soc. Nephrol. JASN 2001, 12, 589-597. [CrossRef]

11. Eltzschig, H.K.; Carmeliet, P. Hypoxia and inflammation. N. Engl. J. Med. 2011, 364, 656-665. [CrossRef] [PubMed]

12. Devarajan, P. Update on Mechanisms of Ischemic Acute Kidney Injury. J. Am. Soc. Nephrol JASN 2006, 17, 1503-1520. Available online: https:/ / pubmed.ncbi.nlm.nih.gov/16707563/ (accessed on 25 October 2021). [CrossRef]

13. Salvadori, M.; Rosso, G.; Bertoni, E. Update on ischemia-reperfusion injury in kidney transplantation: Pathogenesis and treat-ment. World J. Transplant. 2015, 5, 52-67. [CrossRef] [PubMed]

14. Collard, C.D.; Gelman, S. Pathophysiology, clinical manifestations, and prevention of ischemia-reperfusion injury. Anesthesi-ology 2001, 94, 1133-1138. [CrossRef] [PubMed]

15. Versteilen, A.M.G.; Di Maggio, F.; Leemreis, J.R.; Groeneveld, A.B.J.; Musters, R.J.P.; Sipkema, P. Molecular mechanisms of acute renal failure following ischemia/reperfusion. Int. J. Artif. Organs 2004, 27, 1019-1029. [CrossRef] [PubMed]

16. Paller, M.S.; Hoidal, J.R.; Ferris, T.F. Oxygen free radicals in ischemic acute renal failure in the rat. J. Clin. Investig. 1984, 74, 1156-1164. [CrossRef]

17. Taylor, M.J.; Baicu, S.C. Current state of hypothermic machine perfusion preservation of organs: The clinical perspective. Cry-obiology 2010, 60 (Suppl. 3), S20-S35. [CrossRef]

18. O'Callaghan, J.M.; Morgan, R.D.; Knight, S.R.; Morris, P.J. Systematic review and meta-analysis of hypothermic machine perfusion versus static cold storage of kidney allografts on transplant outcomes. Br. J. Surg. 2013, 100, 991-1001. [CrossRef] [PubMed]

19. Rosengard, B.R.; Feng, S.; Alfrey, E.J.; Zaroff, J.G.; Emond, J.C.; Henry, M.L.; Garrity, E.R.; Roberts, J.P.; Wynn, J.J.; Metzger, R.A.; et al. Report of the Crystal City meeting to maximize the use of organs recovered from the cadaver donor. Am. J. Transplant. 2002, 2,701-711. [CrossRef]

20. Rampino, T.; Abelli, M.; Ticozzelli, E.; Gregorini, M.; Bosio, F.; Piotti, G.; Bedino, G.; Esposito, P.; Balenzano, C.T.; Geraci, P.; et al. Non-heart-beating-donor transplant: The first expe-rience in Italy. G Ital. Nefrol. Organo Uff. Della Soc. Ital. Nefrol. 2010, 27, 56-68.

21. Ravaioli, M.; De Pace, V.; Comai, G.; Capelli, I.; Baraldi, O.; D’Errico, A.; Bertuzzo, V.R.; Del Gaudio, M.; Zanfi, C.; D'Arcangelo, G.L.; et al. Preliminary experience of sequential use of normo-thermic and hypothermic oxygenated perfusion for donation after circulatory death kidney with warm ischemia time over the conventional criteria-A retrospective and observational study. Transpl. Int. 2018, 31, 1233-1244. [CrossRef] [PubMed]

22. Tolstykh, G.P.; Gelineau, J.F.; Maier, L.M.; Bunegin, L. Novel portable hypothermic pulsatile perfusion preservation technology: Improved viability and function of rodent and canine kidneys. Ann. Transplant. 2010, 15, 35-43. [PubMed]

23. Ravaioli, M.; Baldassare, M.; Vasuri, F.; Pasquinelli, G.; Laggetta, M.; Valente, S.; De Pace, V.; Neri, F.; Siniscalchi, A.; Zanfi, C.; et al. Strategies to Restore Adenosine Triphosphate (ATP) Level after More than 20 Hours of Cold Ischemia Time in Human Marginal Kidney Grafts. Ann. Transplant. 2018, 23, 34-44. [CrossRef]

24. Jochmans, I.; Akhtar, M.Z.; Nasralla, D.; Kocabayoglu, P.; Boffa, C.; Kaisar, M.; Brat, A.; O'Callaghan, J.; Pengel, L.H.M.; Knight, S.; et al. Past, Present, and Future of Dynamic Kidney and Liver Preservation and Resuscitation. Am. J. Transplant. 2016, 16, 2545-2555. [CrossRef] [PubMed] 
25. Tedesco-Silva, H.; Mello Offerni, J.C.; Carneiro, V.A.; de Paula, M.I.; Neto, E.D.; Lemos, F.B.C.; Moura, L.R.R.; Silva Filho, A.P.; de Morais Cunha, M.d.F.; da Silva, E.F.; et al. Randomized Trial of Machine Perfusion Versus Cold Storage in Recipients of Deceased Donor Kidney Transplants with High Incidence of Delayed Graft Function. Transplant. Direct 2017, 3, e155. [CrossRef]

26. Guarrera, J.V.; Henry, S.D.; Samstein, B.; Reznik, E.; Musat, C.; Lukose, T.I.; Ratner, L.E.; Brown, R.S., Jr.; Kato, T.; Emond, J.C. Hypothermic machine preservation facilitates suc-cessful transplantation of 'orphan' extended criteria donor livers. Am. J. Transplant. 2015, 15, 161-169. [CrossRef]

27. Hosgood, S.A.; Barlow, A.D.; Dormer, J.; Nicholson, M.L. The use of ex-vivo normothermic perfusion for the resuscitation and as-sessment of human kidneys discarded because of inadequate in situ perfusion. J. Transl. Med. 2015, 13, 329. [CrossRef] [PubMed]

28. Hosgood, S.A.; Saeb-Parsy, K.; Hamed, M.O.; Nicholson, M.L. Successful Transplantation of Human Kidneys Deemed Untransplantable but Resuscitated by Ex Vivo Normothermic Machine Perfusion. Am. J. Transplant. 2016, 16, 3282-3285. [CrossRef]

29. Nicholson, M.L.; Hosgood, S.A. Renal transplantation after ex vivo normothermic perfusion: The first clinical study. Am. J. Transplant. 2013, 13, 1246-1252. [CrossRef]

30. Matsuno, N.; Konno, O.; Mejit, A.; Jyojima, Y.; Akashi, I.; Nakamura, Y.; Iwamoto, H.; Hama, K.; Iwahori, T.; Ashizawa, T.; et al. Application of machine perfusion preservation as a viability test for marginal kidney graft. Transplantation 2006, 82, 1425-1428. [CrossRef]

31. Bissolati, M.; Gazzetta, P.G.; Caldara, R.; Guarneri, G.; Adamenko, O.; Giannone, F.; Mazza, M.; Maggi, G.; Tomanin, D.; Rosati, R.; et al. Renal Resistance Trend during Hypo-thermic Machine Perfusion Is More Predictive of Postoperative Outcome than Biopsy Score: Preliminary Experience in 35 Consecutive Kidney Transplantations. Artif. Organs 2018, 42, 714-722. [CrossRef] [PubMed]

32. Ravaioli, M.; De Pace, V.; Angeletti, A.; Comai, G.; Vasuri, F.; Baldassarre, M.; Maroni, L.; Odaldi, F.; Fallani, G.; Caraceni, P.; et al. Hypothermic Oxygenated New Machine Perfu-sion System in Liver and Kidney Transplantation of Extended Criteria Donors: First Italian Clinical Trial. Sci. Rep. 2020, 10, 6063. [CrossRef] [PubMed]

33. Ravaioli, M.; De Pace, V.; Comai, G.; Busutti, M.; Del Gaudio, M.; Amaduzzi, A.; Cucchetti, A.; Siniscalchi, A.; La Manna, G.; D’Errico, A.A.D.; et al. Successful Dual Kidney Transplantation after Hypothermic Oxygenated Perfusion of Discarded Human Kidneys. Am. J. Case Rep. 2017, 18, 1009-1013. [CrossRef] [PubMed]

34. Ravaioli, M.; Corradetti, V.; Renzulli, M.; Germinario, G.; Maroni, L.; Odaldi, F.; Fallani, G.; Pezzuto, A.P.; Parlanti, D.; Bova, R.; et al. Normothermic and hypothermic oxygenated perfusion for donation after circulatory death in kidney transplantation: Do we pay higher risk of severe infection after transplantation?: A case report. BMC Infect. Dis. 2020, 20, 115. [CrossRef] [PubMed]

35. Maroni, L.; Musa, N.; Ravaioli, M.; Dondossola, D.E.; Germinario, G.; Sulpice, L.; Fallani, G.; Pezzuto, A.P.; Parlanti, D.; Bova, R.; et al. Normothermic with or without hypothermic oxygenated perfusion for DCD before liver transplantation: European multicentric experience. Clin. Transplant. 2021, 35, 14448. [CrossRef] [PubMed]

36. Dondossola, D.; Ravaioli, M.; Lonati, C.; Maroni, L.; Pini, A.; Accardo, C.; Germinario, G.; Antonelli, B.; Odaldi, F.; Zanella, A.; et al. The Role of Ex Situ Hypothermic Oxygenated Ma-chine Perfusion and Cold Preservation Time in Extended Criteria Donation after Circulatory Death and Donation after Brain Death. Liver Transplant. 2021, 27, 1130-1143. [CrossRef]

37. Mozzarelli, A.; Ronda, L.; Faggiano, S.; Bettati, S.; Bruno, S. Haemoglobin-based oxygen carriers: Research and reality towards an alternative to blood transfusions. Blood Transfus. 2010, 8 (Suppl. 3), s59-s68.

38. Laing, R.W.; Bhogal, R.H.; Wallace, L.; Boteon, Y.; Neil, D.A.H.; Smith, A.; Stephenson, B.T.F.; Schlegel, A.; Hübscher, S.G.; Mirza, D.-F.; et al. The Use of an Acellular Oxygen Carrier in a Human Liver Model of Normothermic Machine Perfusion. Transplantation 2017, 101, 2746-2756. [CrossRef]

39. Bhattacharjee, R.N.; Patel, S.V.B.; Sun, Q.; Jiang, L.; Richard-Mohamed, M.; Ruthirakanthan, A.; Aquil, S.; Al-Ogaili, R.; Juriasingani, S.; Sener, A.; et al. Renal Protection Against Ische-mia Reperfusion Injury: Hemoglobin-based Oxygen Carrier201 Versus Blood as an Oxygen Carrier in Ex Vivo Subnormo-thermic Machine Perfusion. Transplantation 2020, 104, $482-489$. [CrossRef]

40. Gregorini, M.; Corradetti, V.; Pattonieri, E.F.; Rocca, C.; Milanesi, S.; Peloso, A.; Canevari, S.; De Cecco, L.; Dugo, M.; Avanzini, M.A.; et al. Perfusion of isolated rat kidney with Mesen-chymal Stromal Cells/Extracellular Vesicles prevents ischaemic injury. J. Cell. Mol. Med. 2017, 21, 3381-3393. [CrossRef]

41. Ranghino, A.; Bruno, S.; Bussolati, B.; Moggio, A.; Dimuccio, V.; Tapparo, M.; Biancone, L.; Gontero, P.; Frea, B.; Camussi, G. The effects of glomerular and tubular renal pro-genitors and derived extracellular vesicles on recovery from acute kidney injury. Stem Cell Res. Ther. 2017, 8, 24. [CrossRef]

42. Grange, C.; Bellucci, L.; Bussolati, B.; Ranghino, A. Potential Applications of Extracellular Vesicles in Solid Organ Transplanta-tion. Cells 2020, 9, E369. [CrossRef]

43. Gregorini, M.; Bosio, F.; Rocca, C.; Corradetti, V.; Valsania, T.; Pattonieri, E.F.; Esposito, P.; Bedino, G.; Collesi, C.; Libetta, C.; et al. Mesenchymal stromal cells reset the scatter factor system and cytokine network in experimental kidney transplantation. $B M C$ Immunol. 2014, 15. [CrossRef]

44. De Martino, M.; Zonta, S.; Rampino, T.; Gregorini, M.; Frassoni, F.; Piotti, G.; Bedino, G.; Cobianchi, L.; Dal Canton, A.; Dionigi, P.; et al. Mesenchymal stem cells infusion prevents acute cellular rejection in rat kidney transplantation. Transplant. Proc. 2010, 42, 1331-1335. [CrossRef] [PubMed] 
45. Rampino, T.; Gregorini, M.; Bedino, G.; Piotti, G.; Gabanti, E.; Ibatici, A.; Sessarego, N.; Piacenza, C.; Balenzano, C.T.; Esposito, P.; et al. Mesenchymal stromal cells improve renal injury in anti-Thy 1 nephritis by modulating inflammatory cytokines and scatter factors. Clin. Sci. 2011, 120, 25-36. [CrossRef] [PubMed]

46. Zonta, S.; De Martino, M.; Bedino, G.; Piotti, G.; Rampino, T.; Gregorini, M.; Frassoni, F.; Dal Canton, A.; Dionigi, P.; Alessiani, M. Which is the most suitable and effective route of administration for mesenchymal stem cell-based immunomodulation therapy in experimental kidney transplantation: Endovenous or arterial? Transplant. Proc. 2010, 42, 1336-1340. [CrossRef]

47. Remuzzi, G.; Cravedi, P.; Perna, A.; Dimitrov, B.D.; Turturro, M.; Locatelli, G.; Rigotti, P.; Baldan, N.; Beatini, M.; Valente, U.; et al. Long-term outcome of renal transplantation from older donors. N. Engl. J. Med. 2006, 354, 343-352. [CrossRef] [PubMed]

48. Starzl, T.E.; Miller, C.; Broznick, B.; Makowka, L. An improved technique for multiple organ harvesting. Surg. Gynecol. Obstet. 1987, 165, 343-348. [PubMed]

49. Bruno, S.; Grange, C.; Deregibus, M.C.; Calogero, R.A.; Saviozzi, S.; Collino, F.; Morando, L.; Busca, A.; Falda, M.; Bussolati, B.; et al. Mesenchymal stem cell-derived microvesicles protect against acute tubular injury. J. Am. Soc. Nephrol. JASN 2009, 20, 1053-1067. [CrossRef] [PubMed]

50. Tapparo, M.; Bruno, S.; Collino, F.; Togliatto, G.; Deregibus, M.C.; Provero, P.; Wen, S.; Quesenberry, P.J.; Camussi, G. Renal Regenerative Potential of Extracellular Vesicles Derived from miRNA-Engineered Mesenchymal Stromal Cells. Int. J. Mol. Sci. 2019, 20, E2381. [CrossRef]

51. Bruno, S.; Tapparo, M.; Collino, F.; Chiabotto, G.; Deregibus, M.C.; Soares Lindoso, R.; Neri, F.; Kholia, S.; Giunti, S.; Wen, S.; et al. Renal Regenerative Potential of Differ-ent Extracellular Vesicle Populations Derived from Bone Marrow Mesenchymal Stromal Cells. Tissue Eng. Part A 2017, 23, 1262-1273. [CrossRef] [PubMed]

52. Collino, F.; Pomatto, M.; Bruno, S.; Lindoso, R.S.; Tapparo, M.; Sicheng, W.; Quesenberry, P.; Camussi, G. Exosome and Microvesicle-Enriched Fractions Iso-lated from Mesenchymal Stem Cells by Gradient Separation Showed Different Molecular Signatures and Functions on Renal Tubular Epithelial Cells. Stem Cell Rev. Rep. 2017, 13, 226-243. [CrossRef] [PubMed]

53. Kholia, S.; Herrera Sanchez, M.B.; Cedrino, M.; Papadimitriou, E.; Tapparo, M.; Deregibus, M.C.; Bruno, S.; Antico, F.; Brizzi, M.F.; Quesenberry, P.J.; et al. Mesenchymal Stem Cell De-rived Extracellular Vesicles Ameliorate Kidney Injury in Aristolochic Acid Nephropathy. Front. Cell Dev. Biol. 2020, 8, 188. [CrossRef]

54. Zhou, Y.; Jia, Y.; Buehler, P.W.; Chen, G.; Cabrales, P.; Palmer, A.F. Synthesis, biophysical properties, and oxygenation potential of variable molecular weight glutaraldehyde-polymerized bovine hemoglobins with low and high oxygen affinity. Biotechnol. Prog. 2011, 27, 1172-1184. [CrossRef]

55. Spyrakis, F.; Bruno, S.; Bidon-Chanal, A.; Luque, F.J.; Abbruzzetti, S.; Viappiani, C.; Dominici, P.; Mozzarelli, A. Oxygen binding to Arabidopsis thaliana $\mathrm{AHb} 2$ nonsymbiotic hemoglobin: Evidence for a role in oxygen transport. IUBMB Life 2011, 63, 355-362 [CrossRef] [PubMed]

56. Ronda, L.; Bruno, S.; Faggiano, S.; Bettati, S.; Mozzarelli, A. Oxygen binding to heme proteins in solution, encapsulated in silica gels, and in the crystalline state. Methods Enzymol. 2008, 437, 311-328.

57. Eike, J.H.; Palmer, A.F. Effect of glutaraldehyde concentration on the physical properties of polymerized hemoglobin-based oxygen carriers. Biotechnol. Prog. 2004, 20, 1225-1232. [CrossRef] [PubMed]

58. Crowe, A.R.; Yue, W. Semi-quantitative Determination of Protein Expression UsingImmunohistochemistry Staining and Analysis: An Integrated Protocol. Bio-Protocol 2019, 9, e3465. [CrossRef]

59. EL Andaloussi, S.; Mäger, I.; Breakefield, X.O.; Wood, M.J.A. Extracellular vesicles: Biology and emerging therapeutic opportunities. Nat. Rev. Drug Discov. 2013, 12, 347-357. [CrossRef]

60. Desrochers, L.M.; Bordeleau, F.; Reinhart-King, C.A.; Cerione, R.A.; Antonyak, M.A. Microvesicles provide a mechanism for inter-cellular communication by embryonic stem cells during embryo implantation. Nat. Commun. 2016, 7, 11958. [CrossRef]

61. Johnsen, K.B.; Gudbergsson, J.M.; Skov, M.N.; Pilgaard, L.; Moos, T.; Duroux, M. A comprehensive overview of exosomes as drug delivery vehicles-Endogenous nanocarriers for targeted cancer therapy. Biochim. Biophys. Acta 2014, 1846, 75-87. [CrossRef] [PubMed]

62. Grange, C.; Skovronova, R.; Marabese, F.; Bussolati, B. Stem Cell-Derived Extracellular Vesicles and Kidney Regeneration. Cells 2019, 8, E1240. [CrossRef] [PubMed]

63. Quesenberry, P.J.; Aliotta, J.; Deregibus, M.C.; Camussi, G. Role of extracellular RNA-carrying vesicles in cell differentiation and reprogramming. Stem Cell Res. Ther. 2015, 6, 153. [CrossRef] [PubMed]

64. Valadi, H.; Ekström, K.; Bossios, A.; Sjöstrand, M.; Lee, J.J.; Lötvall, J.O. Exosome-mediated transfer of mRNAs and microRNAs is a novel mechanism of genetic exchange between cells. Nat. Cell Biol. 2007, 9, 654-659. [CrossRef] [PubMed]

65. Ratajczak, M.Z.; Ratajczak, J. Horizontal transfer of RNA and proteins between cells by extracellular microvesicles: 14 years later. Clin. Transl. Med. 2016, 5, 7. [CrossRef] [PubMed]

66. Deregibus, M.C.; Cantaluppi, V.; Calogero, R.; Lo Iacono, M.; Tetta, C.; Biancone, L.; Bruno, S.; Bussolati, B.; Camussi, G. Endothelial progenitor cell derived mi-crovesicles activate an angiogenic program in endothelial cells by a horizontal transfer of mRNA. Blood 2007, 110, 2440-2448. [CrossRef]

67. Hur, Y.H.; Cerione, R.A.; Antonyak, M.A. Extracellular vesicles and their roles in stem cell biology. Stem Cells 2020, 38, 469-476. [CrossRef] [PubMed] 
68. Chemistry and Biochemistry of Oxygen Therapeutics. Available online: https://blackwells.co.uk/bookshop/product/ Chemistry-and-Biochemistry-of-Oxygen-Therapeutics-by-Andrea-Mozzarelli-Stefano-Bettati/9780470686683 (accessed on 22 November 2021).

69. Silverman, T.A.; Weiskopf, R.B. Planning Committee and the Speakers. Hemoglobin-based oxygen carriers: Current status and future directions. Anesthesiology 2009, 111, 946-963. [CrossRef]

70. Vandegriff, K.D.; Malavalli, A.; Wooldridge, J.; Lohman, J.; Winslow, R.M. MP4, a new nonvasoactive PEG-Hb conjugate. Transfusion 2003, 43, 509-516. [CrossRef]

71. Buehler, P.W.; Boykins, R.A.; Norris, S.; Alayash, A.I. Chemical characterization of diaspirin cross-linked hemoglobin polymer-ized with poly(ethylene glycol). Anal. Chem. 2006, 78, 4634-4641. [CrossRef]

72. Cole, R.H.; Vandegriff, K.D. MP4, a vasodilatory PEGylated hemoglobin. Adv. Exp. Med. Biol. 2011, 701, 85-90.

73. Jahr, J.S.; Akha, A.S.; Holtby, R.J. Crosslinked, polymerized, and PEG-conjugated hemoglobin-based oxygen carriers: Clinical safety and efficacy of recent and current products. Curr. Drug Discov. Technol. 2012, 9, 158-165. [CrossRef]

74. Portöro, I.; Kocsis, L.; Hermán, P.; Caccia, D.; Perrella, M.; Ronda, L.; Bruno, S.; Bettati, S.; Micalella, C.; Mozzarelli, A.; et al. Towards a novel haemoglobin-based oxygen carrier: Euro-PEG-Hb, physico-chemical properties, vasoactivity and renal filtration. Biochim. Biophys. Acta 2008, 1784, 1402-1409. [CrossRef]

75. Sprung, J.; Kindscher, J.D.; Wahr, J.A.; Levy, J.H.; Monk, T.G.; Moritz, M.W.; O'Hara, P.J. The use of bovine hemoglobin glutamer250 (Hemopure) in surgical patients: Results of a multicenter, randomized, single-blinded trial. Anesth. Analg. 2002, 94, 799-808, table of contents. [CrossRef] [PubMed]

76. Levy, J.H.; Goodnough, L.T.; Greilich, P.E.; Parr, G.V.S.; Stewart, R.W.; Gratz, I.; Wahr, J.; Williams, J.; Comunale, M.E.; Doblar, D.; et al. Polymerized bovine hemoglobin solution as a replacement for allogeneic red blood cell transfusion after cardiac surgery: Results of a randomized, double-blind trial. J. Thorac. Cardiovasc. Surg. 2002, 124, 35-42. [CrossRef] [PubMed]

77. Faggiano, S.; Bruno, S.; Ronda, L.; Pizzonia, P.; Pioselli, B.; Mozzarelli, A. Modulation of expression and polymerization of hemo-globin Polytaur, a potential blood substitute. Arch. Biochem. Biophys. 2011, 505, 42-47. [CrossRef] [PubMed]

78. Chang, T.M.S. Nanobiotechnology for hemoglobin-based blood substitutes. Crit. Care Clin. 2009, 25, 373-382. [CrossRef]

79. Chang, T.M. Blood substitutes based on modified hemoglobin prepared by encapsulation or crosslinking: An overview. Bio-Mater. Artif. Cells Immobil. Biotechnol. 1992, 20, 159-179. [CrossRef] [PubMed]

80. Arifin, D.R.; Palmer, A.F. Polymersome encapsulated hemoglobin: A novel type of oxygen carrier. Biomacromolecules 2005, 6 , 2172-2181. [CrossRef] [PubMed]

81. Sakai, H.; Takeoka, S.; Park, S.I.; Kose, T.; Nishide, H.; Izumi, Y.; Yoshizu, A.; Kobayashi, K.; Tsuchida, E. Surface modification of hemoglobin vesicles with poly(ethylene glycol) and effects on aggregation, viscosity, and blood flow during $90 \%$ exchange transfusion in anesthetized rats. Bioconjugate Chem. 1997, 8, 23-30. [CrossRef]

82. Meng, F.; Kassa, T.; Jana, S.; Wood, F.; Zhang, X.; Jia, Y.; D’Agnillo, F.; Alayash, A.I. Comprehensive Biochemical and Biophysical Characterization of Hemoglobin-Based Oxygen Carrier Therapeutics: All HBOCs Are Not Created Equally. Bioconjugate Chem. 2018, 29, 1560-1575. [CrossRef] [PubMed]

83. Huang, J.; Li, R.; Wang, C. The Role of Mitochondrial Quality Control in Cardiac Ischemia/Reperfusion Injury. Oxidative Med. Cell. Longev. 2021, 2021, 5543452. [CrossRef] [PubMed]

84. Baniene, R.; Trumbeckas, D.; Kincius, M.; Pauziene, N.; Raudone, L.; Jievaltas, M.; Trumbeckaite, S. Short ischemia induces rat kidney mito-chondria dysfunction. J. Bioenerg. Biomembr. 2016, 48, 77-85. [CrossRef]

85. Fukuda, R.; Zhang, H.; Kim, J.; Shimoda, L.; Dang, C.V.; Semenza, G.L. HIF-1 regulates cytochrome oxidase subunits to optimize ef-ficiency of respiration in hypoxic cells. Cell 2007, 129, 111-122. [CrossRef]

86. von Ahsen, O.; Newmeyer, D.D. Cell-free apoptosis in Xenopus laevis egg extracts. Methods Enzymol. 2000, 322, $183-198$.

87. Medica, D.; Franzin, R.; Stasi, A.; Castellano, G.; Migliori, M.; Panichi, V.; Figliolini, F.; Gesualdo, L.; Camussi, G.; Cantaluppi, V. Extracellular Vesicles Derived from Endothelial Progenitor Cells Protect Human Glomerular Endothelial Cells and Podocytes from Complement- and Cytokine-Mediated Injury. Cells 2021, 10, 1675. [CrossRef]

88. Rampino, T.; Gregorini, M.; Dal Canton, A. Scatter Factors in renal disease: Dr. Jeckyll and Mr. Hyde? Cytokine Growth Factor Rev. 2009, 20, 77-85. [CrossRef] [PubMed]

89. Rampino, T.; Gregorini, M.; Guidetti, C.; Broggini, M.; Marchini, S.; Bonomi, R.; Maggio, M.; Roscini, E.; Soccio, G.; Tiboldo, R.; et al. KCNA1 and TRPC6 ion channels and NHE1 exchanger operate the biological outcome of HGF/scatter factor in renal tubular cells. Growth Factors 2007, 25, 382-391. [CrossRef]

90. Buehler, P.W.; D'Agnillo, F.; Schaer, D.J. Hemoglobin-based oxygen carriers: From mechanisms of toxicity and clearance to ra-tional drug design. Trends Mol. Med. 2010, 16, 447-457. [CrossRef]

91. Natanson, C.; Kern, S.J.; Lurie, P.; Banks, S.M.; Wolfe, S.M. Cell-free hemoglobin-based blood substitutes and risk of myocardial infarction and death: A meta-analysis. JAMA 2008, 299, 2304-2312. [CrossRef]

92. Burhop, K.; Gordon, D.; Estep, T. Review of hemoglobin-induced myocardial lesions. Artif. Cells Blood Substit. Immobil. Biotecnol. 2004, 32, 353-374. [CrossRef] [PubMed]

93. Rentsendorj, O.; Zhang, X.; Williams, M.C.; Buehler, P.W.; D’Agnillo, F. Transcriptional Suppression of Renal Antioxidant Enzyme Systems in Guinea Pigs Exposed to Polymerized Cell-Free Hemoglobin. Toxics 2016, 4, 6. [CrossRef] [PubMed] 
94. Alomari, E.; Ronda, L.; Bruno, S.; Paredi, G.; Marchetti, M.; Bettati, S.; Olivari, D.; Fumagalli, F.; Novelli, D.; Ristagno, G.; et al. High- and low-affinity PEGylated hemoglobin-based oxygen carriers: Differential oxidative stress in a Guinea pig transfusion model. Free Radic. Biol. Med. 2018, 124, 299-310. [CrossRef]

95. Buehler, P.W.; Alayash, A.I. Toxicities of hemoglobin solutions: In search of in-vitro and in-vivo model systems. Transfusion 2004, 44, 1516-1530. [CrossRef]

96. Elliott, T.R.; Nicholson, M.L.; Hosgood, S.A. Normothermic kidney perfusion: An overview of protocols and strategies. Am. J. Transplant. 2021, 21, 1382-1390. [CrossRef] [PubMed]

97. White, C.W.; Hasanally, D.; Mundt, P.; Li, Y.; Xiang, B.; Klein, J.; Müller, A.; Ambrose, E.; Ravandi, A.; Arora, R.C.; et al. A whole blood-based perfusate provides superior preserva-tion of myocardial function during ex vivo heart perfusion. J. Heart Lung Transplant. 2015, 34, 113-121. [CrossRef]

98. Matton, A.P.M.; Burlage, L.C.; van Rijn, R.; de Vries, Y.; Karangwa, S.A.; Nijsten, M.W.; Gouw, A.S.H.; Wiersema-Buist, J.; Adelmeijer, J.; Westerkamp, A.C.; et al. Normothermic machine perfusion of do-nor livers without the need for human blood products. Liver Transplant. 2018, 24, 528-538. [CrossRef]

99. Boteon, Y.L.; Laing, R.W.; Schlegel, A.; Wallace, L.; Smith, A.; Attard, J.; Bhogal, R.H.; Reynolds, G.; Perera, M.T.P.R.; Muiesan, P.; et al. The impact on the bioenergetic status and oxida-tive-mediated tissue injury of a combined protocol of hypothermic and normothermic machine perfusion using an acellular haemoglobin-based oxygen carrier: The cold-to-warm machine perfusion of the liver. PLoS ONE 2019, 14, e0224066. [CrossRef]

100. De Vries, Y.; Matton, A.P.M.; Nijsten, M.W.N.; Werner, M.J.M.; van den Berg, A.P.; de Boer, M.T.; Buis, C.I.; Fujiyoshi, M.; de Kleine, R.H.J.; van Leeuwen, O.B.; et al. Pretransplant sequential hypo- and normothermic machine perfusion of suboptimal livers donated after circulatory death using a hemoglobin-based oxy-gen carrier perfusion solution. Am. J. Transplant. 2019, 19, 1202-1211. [CrossRef] [PubMed]

101. Aburawi, M.M.; Fontan, F.M.; Karimian, N.; Eymard, C.; Cronin, S.; Pendexter, C.; Nagpal, S.; Banik, P.; Ozer, S.; Mahboub, P.; et al. Synthetic hemoglobin-based oxygen carriers are an acceptable alternative for packed red blood cells in normothermic kidney perfusion. Am. J. Transplant. 2019, 19, 2814-2824. [CrossRef]

102. Mahboub, P.; Aburawi, M.; Karimian, N.; Lin, F.; Karabacak, M.; Fontan, F.; Markmann, J.; Yeh, H.; Uygun, K. The efficacy of HBOC-201 in ex situ gradual re-warming kidney perfusion in a rat model. Artif. Organs 2020, 44, 81-90. [CrossRef] [PubMed]

103. Juriasingani, S.; Jackson, A.; Zhang, M.Y.; Ruthirakanthan, A.; Dugbartey, G.J.; Sogutdelen, E.; Levine, M.; Mandurah, M.; Whiteman, M.; Luke, P.; et al. Evaluating the Effects of Subnormothermic Perfusion with AP39 in a Novel Blood-Free Model of Ex Vivo Kidney Preservation and Reperfusion. Int. J. Mol. Sci. 2021, 22, 7180. [CrossRef] [PubMed]

104. Mathew, B.; Ravindran, S.; Liu, X.; Torres, L.; Chennakesavalu, M.; Huang, C.-C.; Feng, L.; Zelka, R.; Lopez, J.; Sharma, M.; et al. Mesenchymal stem cell-derived ex-tracellular vesicles and retinal ischemia-reperfusion. Biomaterials 2019, 197, 146-160. [CrossRef] [PubMed] 